\title{
Engineering Human Epidermal Growth Receptor 2-Targeting Hepatitis B Virus Core Nanoparticles for siRNA Delivery in Vitro and in Vivo
}

Izzat F. M. Suffian, ${ }^{\dagger} \S$ Julie T.-W. Wang, ${ }^{\dagger}$ Farid N. Faruqu, $^{\dagger}$ Julio Benitez, $^{\dagger}$ Yuya Nishimura, ${ }^{\ddagger}$ Chiaki Ogino, ${ }^{\ddagger}$ Akihiko Kondo, ${ }^{\ddagger}$ and Khuloud T. Al-Jamal* ${ }^{\dagger} \dagger$ (1)

${ }^{\dagger}$ Institute of Pharmaceutical Science, King’s College London, Franklin-Wilkins Building, 150 Stamford Street, London SE1 9NH, U.K.

${ }^{\ddagger}$ Department of Chemical Science and Engineering, Graduate School of Engineering, Kobe University, 1-1 Rokkodai, Nada, Kobe 657-8501, Japan

\section{Supporting Information}

ABSTRACT: Hepatitis B virus core $(\mathrm{HBc})$ particles acquire the capacity to disassemble and reassemble in a controlled manner, allowing entrapment and delivery of drugs and macromolecules to cells. HBc particles are made of 180-240 copies of $21 \mathrm{kDa}$ protein monomers, assembled into 30-34 $\mathrm{nm}$ diameter icosahedral particles. In this study, we aimed at formulating $\mathrm{HBc}$ particles for the delivery of siRNA for gene silencing in vitro and in vivo. We have previously reported recombinant $\mathrm{HBc}$ particles expressing $\mathrm{Z}_{\mathrm{HER} 2}$ affibodies, specifically targeting human epidermal growth receptor 2

(HER2)-expressing cancer cells $\left(\mathrm{Z}_{\mathrm{HER} 2}-\Delta \mathrm{HBc}\right)$. siRNA was encapsulated within the $\mathrm{Z}_{\mathrm{HER} 2}-\Delta \mathrm{HBc}$ particles following disassembly and reassembly. The $Z_{\mathrm{HER} 2}-\Delta \mathrm{HBc}-$ siRNA hybrids were able to secure the encapsulated siRNA from serum and nucleases in vitro. Enhanced siRNA uptake in HER2-expressing cancer cells treated with $\mathrm{Z}_{\mathrm{HER} 2}-\Delta \mathrm{HBc}-$ siRNA hybrids was observed compared to the nontargeted $\mathrm{HBc}$-siRNA hybrids in a time- and dose-dependent manner. A successful in vitro pololike kinase 1 (PLK1) gene knockdown was demonstrated in cancer cells treated with $\mathrm{Z}_{\mathrm{HER} 2}-\Delta \mathrm{HBc}-$ siPLK1 hybrids, to levels comparable to commercial transfecting reagents. Interestingly, $\mathrm{Z}_{\mathrm{HER} 2}-\Delta \mathrm{HBc}$ particles exhibit intrinsic capability of reducing the solid tumor mass, independent of siPLK1 therapy, in an intraperitoneal tumor model following intraperitoneal injection.

KEYWORDS: virus-like particles, hepatitis B virus core particles, human epidermal growth factor receptor 2, affibody, gene silencing

\section{INTRODUCTION}

RNA interference (RNAi) is a biological mechanism whereby small noncoding double-stranded RNAs (dsRNA) interfere with the expression of a particular gene that shares homologous sequence with dsRNA. ${ }^{1}$ Once small interference RNA (siRNA), 20-30 nucleotide dsRNA, is present in the cytoplasm of the cell, it is incorporated into a protein complex known as RNA induced silencing complex (RISC). The whole construct can induce a selective endonucleolytic cleavage of the complementary target mRNA, which propagates gene silencing. $^{2-5}$ Gene silencing has been of great interest as a powerful therapeutic strategy to regulate diseases of disordered gene origin, including cancer. ${ }^{6,7}$ However, the therapeutic applications of siRNA have been limited, due to its high molecular weight and anionic charge, which causes difficulty for siRNA to penetrate the cellular membranes by passive diffusion mechanisms. ${ }^{8}$ In addition, siRNA activity is greatly limited by rapid enzymatic degradation due to the presence of ribonucleases (RNases) in serum. ${ }^{9}$

In order to achieve efficient cytoplasmic delivery of siRNA in vitro and in vivo, delivery systems using nanoparticles have been employed by researchers, including nonviral delivery systems such as cationic liposomes, polymers, and carbon nanotubes, and viral delivery systems such as viral-like particles (VLPs). ${ }^{10-13}$ VLPs are hollow protein capsids derived from viruses but lacking the viral genomes. They are ideal bionanocarriers due to their biocompatibility, regulated structure, and homogeneous size. ${ }^{14}$ Many medical applications, including vaccine development and delivery of peptides and nucleic acids have been approached using VLPs. ${ }^{15,16}$ Hepatitis B virus core $(\mathrm{HBc})$ particles are one of the VLPs that have been investigated by researchers as nanocarriers for drug delivery. ${ }^{17-19} \mathrm{HBc}$ particles are hollow nanoparticles $(30-34 \mathrm{~nm}$ in diameter), consisting of 180-240 copies of core monomers. ${ }^{20}$ Like other VLPs, $\mathrm{HBc}$ particles are noninfectious but still inherit the essential features of the hepatitis B virus, including the cell-penetrating ability. They also have the capability to assemble and disassemble in a controlled manner allowing

Received: March 27, 2018

Accepted: June 4, 2018

Published: June 20, 2018 
encapsulation of biomolecules including oligonucleotides. ${ }^{21,22}$ In addition, $\mathrm{HBc}$ particles can be genetically modified with targeting molecules on the surface, which is beneficial for sitespecific delivery. ${ }^{23}$ These features make $\mathrm{HBc}$ particles suitable candidates for delivery of therapeutics.

In this study, we aimed at formulating the $\mathrm{HBc}$ particles that specifically target human epidermal growth receptor 2 (HER2)-expressing cancer cells, for the delivery of siRNA and gene silencing in vitro and in vivo (Scheme 1). Polo-like

Scheme 1. Description of the Proposed HBc-Based siRNA Nanocarrier

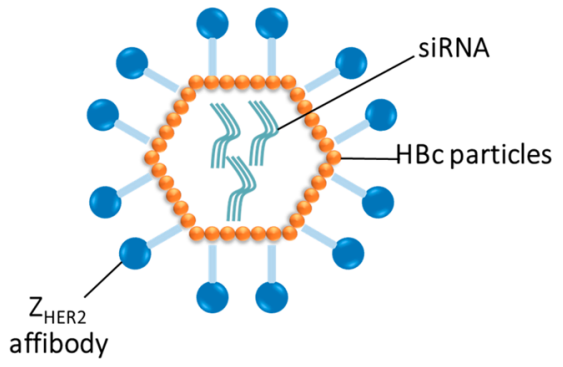

kinase (PLK1), a serine/threonine kinase that has key roles in cell division and checkpoint regulation of mitosis, was chosen as the targeting gene. PLK1 is known to overexpress in several types of cancer and siRNA-mediated silencing of PLK1 in cancer cells has been shown to result in reduced cell viability with induction of apoptosis after depletion of PLK1 protein. $^{24,25}$ We hypothesized that the HER2-targeting HBc particles would be able to encapsulate and deliver the functional siRNA (siPLK1) in vitro and induce gene silencing in cancer cells in vitro causing cell death. We also hypothesized that the encapsulation strategy is likely to improve the longevity of siRNA in vivo following local administration. $\mathrm{HBc}$ particles were prepared and characterized using E. coli expression system. siRNA was encapsulated into $\mathrm{HBc}$ particles using three different methods: disassembly and reassembly in the presence of urea, osmotic shock, or disassembly and reassembly by dithiothreitol (DTT) $/ \mathrm{CaCl}_{2}$ treatment. siRNA encapsulation efficiency was determined by gel retardation and aldehyde sulfate latex beads assay. Cancer cells were treated with $\mathrm{HBc}-$ siRNA hybrid particles, and the cell uptake was assessed by flow cytometry. Cell cytotoxicity and gene silencing of cancer cells treated with $\mathrm{HBc}-$ siPLK1 hybrid particles were assessed using MTT assay and immunostaining by Western blotting. In vivo silencing efficacy was assessed using an intraperitoneal HER-2 expressing tumor model ${ }^{20}$ following intraperitoneal administration.

\section{EXPERIMENTAL SECTION}

2.1. Materials. Lithium chloride and ethylene glycol-bis $(\beta$ aminoethyl ether)- $N, N, N^{\prime}, N^{\prime}$-tetraacetic acid (EGTA) were obtained from Amresco (USA). Ethylenediaminetetraacetic acid (EDTA) disodium and dithiothreitol (DTT) were obtained from ForMedium (UK). Calcium chloride (anhydrous) and urea (carbamide) were obtained from Melford (UK). Ribonuclease A (from bovine pancreas), MTT (3-(4,5-dimethylthiazol-2-yl)-2,5-diphenyltetrazolium bromide), and dimethylsulfoxide (DMSO) were obtained from Sigma-Aldrich (UK). Bovine serum albumin, lyophilized powder, $\geq 96 \%$ (agarose gel electrophoresis), was obtained from Sigma-Aldrich (Germany). BD OptEIA Mouse TNF (Mono/Mono) ELISA kit was obtained from BD Biosciences, USA. XenoLight D-luciferin potassium salt was obtained from PerkinElmer (EU). GAPDH (14C10) rabbit
$\mathrm{mAb}$, anti-rabbit IgG HRP-linked antibody, and anti-mouse IgG HRP-linked antibody were obtained from Cell Signaling Technology (UK). Anti-PLK1 antibody (35-206) was obtained from Abcam (UK). Heat inactivated newborn calf serum (FBS) was obtained from First Link Limited (UK). Lipofectamine2000, aldehyde/sulfate latex $(4 \% \mathrm{w} / \mathrm{v}, 4 \mu \mathrm{m})$, Alexa Fluor 488 NHS ester (succinimidyl ester), MEM GlutaMAX Supplement, DMEM high glucose pyruvate, advanced RPMI 1640 medium, PBS (10×) pH 7.4, trypsin-EDTA (0.05\%) phenol red, penicillin-streptomycin $(10000 \mathrm{U} / \mathrm{mL})$, Lglutamine $(200 \mathrm{mM})$, GlutaMAX Supplement, SnakeSkin dialysis tubing (10000 MWCO, $35 \mathrm{~mm}$ ) and Pierce 16\% formaldehyde (w/v, methanol-free), Pierce BCA Protein Assay Kit were purchased from Thermo-Fisher Scientific (UK). Noncoding siRNA (siNEG) (antisense sequence, 5'-CAUCGUCGAUCGUAGCGCAA-3'), Atto-655labeled siNEG, and siPLK-1 (sequence 5'-CCUUGAUGAAGAAGAUCACdTdT-3') were obtained from Eurogentec (Belgium). Precision Protein StrepTactin-HRP conjugate was purchased from Bio-Rad Laboratories, USA. Heparin (5000 IU/mL) (Sigma, UK) was obtained from St. Thomas's Hospital, UK. Plasmids pET-22b(+)$\mathrm{dc} 149$-His6 and pET-22b(+)-dc149-Z342-His6 were obtained from Associate Professor Chiaki Ogino, Chemical and Science Engineering Department, Kobe University, Japan.

2.2. Expression, Purification, and Assembly of $\mathrm{HBc}$ Particles. Expression, purification, and assembly of $\Delta \mathrm{HBc}$ and $\mathrm{Z}_{\mathrm{HER} 2}-\Delta \mathrm{HBc}$ particles were performed as previously published by Suffian et al. ${ }^{20}$ and detailed in SI. Protein concentrations of assembled $\triangle \mathrm{HBc}$ and $\mathrm{Z}_{\mathrm{HER} 2}-\Delta \mathrm{HBc}$ particles were measured using NanoDrop ND-1000 UV-vis spectrophotometer (Thermo Fisher Scientific, USA).

2.3. siRNA Encapsulation in $\mathrm{HBC}$ Particles. Encapsulation of siRNA into $\mathrm{Z}_{\mathrm{HER}^{2}}-\Delta \mathrm{HBc}$ particles was performed using three methods mentioned below. Fluorescently labeled nonfunctional siRNA, siNEG ${ }_{\text {Atto655 }}$ with emission at $650 \mathrm{~nm}$, and $\mathrm{Z}_{\mathrm{HER} 2}-\Delta \mathrm{HBc}_{\mathrm{AF} 480}$ with emission at $525 \mathrm{~nm}$ were employed to assess encapsulation efficiency.

2.3.1. Method I: Disassembly/Reassembly Using Urea/NaCl. Fluorescently labeled $\mathrm{Z}_{\mathrm{HER} 2}-\Delta \mathrm{HBc}_{\mathrm{AF} 480}$ particles $(30,60,120$ (1:1 $\mathrm{HBc} / \mathrm{siNEG}$ molar ratio), $240,480 \mu \mathrm{g}$ ) were dialyzed against $1 \mathrm{~L}$ of disassembly buffer containing $1.5 \mathrm{M}$ urea, $0.5 \mathrm{M} \mathrm{LiCl}, 50 \mathrm{mM}$ Tris, and $5 \mathrm{mM}$ dithiothreitol (DTT) at $4{ }^{\circ} \mathrm{C}$ overnight to disassemble $\mathrm{HBc}$ particles into monomers. For siRNA encapsulation, siNEG Atto65s $(0.25 \mu \mathrm{g})$ was mixed with $\mathrm{Z}_{\mathrm{HER} 2}-\Delta \mathrm{HBc}_{\mathrm{AF} 480}$ in its disassembled form, incubated for $1 \mathrm{~h}$ at $20{ }^{\circ} \mathrm{C}$, and then dialyzed against $1 \mathrm{~L}$ of reassembly buffer containing $50 \mathrm{mM}$ Tris, $1 \mathrm{M} \mathrm{NaCl}$ overnight at 4 ${ }^{\circ} \mathrm{C}$ to reassemble the particles. Samples were concentrated to $100 \mu \mathrm{L}$ final volume using Vivaspin tubes (MWCO $10 \mathrm{kDa}$ ). To assess the degree of complexation, samples were loaded onto $1 \%$ agarose gel , followed by gel electrophoresis at $100 \mathrm{~V}$ for $45 \mathrm{~min}$ for gel retardation assay. Gel was then visualized under Alexa Fluor 647 and Alexa Fluor 488 channels using ChemiDocMP system (Bio-Rad Laboratories, USA).

2.3.2. Method II: Osmotic Shock. Fluorescently labeled $\mathrm{Z}_{\mathrm{HER} 2}$ $\Delta \mathrm{HBc}_{\mathrm{AF} 480}$ particles $(30,60,120,240$, and $480 \mu \mathrm{g})$ were mixed with $0.25 \mu \mathrm{g}$ of siNEG $\mathrm{Atto655}_{5}$ in $1 \times \mathrm{PBS}$ and incubated for $10 \mathrm{~min}$ at $37^{\circ} \mathrm{C}$. Osmotic shock was achieved by $5 \times$ dilution with distilled water. Samples were incubated for $20 \mathrm{~min}$ at $37^{\circ} \mathrm{C}$ then concentrated to 100 $\mu \mathrm{L}$ volume using Vivaspin tubes (MWCO $10 \mathrm{kDa}$ ). Samples were loaded onto $1 \%$ agarose gel, underwent gel retardation assay, and were then imaged using ChemiDocMP system as described previously.

2.3.3. Method III: Disassembly/Reassembly Using EGTA/CaCl${ }_{2}$. Fluorescently labeled $\mathrm{Z}_{\mathrm{HER} 2}-\Delta \mathrm{HBc}_{\mathrm{AF} 480}$ particles $(30,60,120,240$, and $480 \mu \mathrm{g}$ ) were incubated with a disassembly buffer containing 50 $\mathrm{mM}$ Tris, $150 \mathrm{mM} \mathrm{NaCl}, 1 \mathrm{mM}$ EGTA, and $20 \mathrm{mM}$ dithiothreitol (DTT) $(\mathrm{pH} 7.4)$ at $1: 1$ volume ratio for $1 \mathrm{~h}$ at $20^{\circ} \mathrm{C}$. For siRNA encapsulation, siNEG Atto655 $(0.25 \mu \mathrm{g})$ was mixed with the disassembled $\mathrm{HBc}$ and incubated for $1 \mathrm{~h}$ at $20{ }^{\circ} \mathrm{C}$. To reassemble the particles, $0.1 \mathrm{M} \mathrm{CaCl}_{2}$ was slowly added to the mixture to reach a final $\mathrm{CaCl}_{2}$ concentration of $10 \mathrm{mM}$. Samples were incubated for another $1 \mathrm{~h}$ at $20{ }^{\circ} \mathrm{C}$ and kept overnight at $4{ }^{\circ} \mathrm{C}$. Samples were concentrated to $100 \mu \mathrm{L}$ using Vivaspin tubes (MWCO $10 \mathrm{kDa}$ ). Samples were loaded onto $1 \%$ agarose gel and underwent gel 
retardation assay then imaged using ChemiDocMP system as described previously.

In all methods, samples were buffer-exchanged to $1 \times$ PBS prior to addition to cells to maintain isotonicity.

2.4. Flow Cytometry Analysis of $\mathrm{HBC}-$ siNEG Hybrid Particles. To confirm siNEG ${ }_{\text {Atto655 }}$ encapsulation within $Z_{\mathrm{HER2}-}$ $\Delta \mathrm{HBc}_{\mathrm{AF} 480}$ particles, flow cytometry analysis of $\mathrm{HBc}-$ siNEG particles was performed. $\mathrm{HBc}$ particles were fluorescently labeled with Alexa Fluor 488 as previously described. ${ }^{20} \mathrm{HBc}-$ siNEG hybrid particles were encapsulated at 1:1 $\mathrm{HBc} / \mathrm{siNEG}$ molar ratio by the three different encapsulation methods. Prepared $\mathrm{HBc}-$ siNEG hybrid particles were reacted with aldehyde/sulfate latex $(4 \% \mathrm{w} / \mathrm{v}, 4 \mu \mathrm{m})$ microbeads (Invitrogen, USA) as previously described for other proteins, with some modification. ${ }^{27} \mathrm{HBc}-$ siNEG hybrid particles $(40$ $\mu \mathrm{L})$ were incubated with $10 \mu \mathrm{L}$ of aldehyde/sulfate latex ( $4 \% \mathrm{w} / \mathrm{v}, 4$ $\mu \mathrm{m})$ microbeads in a final volume of $500 \mu \mathrm{L}$ for $15 \mathrm{~min}$ at room temperature. Then, final concentration of $10 \mu \mathrm{M}$ BSA from $100 \mu \mathrm{M}$ stock solution was added to each sample and incubated for another 15 $\mathrm{min}$ at room temperature. Then, an incubation in $1 \mathrm{~mL}$ of PBS was conducted for another $75 \mathrm{~min}$ with gentle shaking; reaction was stopped by incubation with $1 \mathrm{~mL}$ of $100 \mathrm{mM}$ glycine made in PBS for $30 \mathrm{~min}$ at room temperature. $\mathrm{HBc}-$ siNEG-coated beads were then washed twice in $1 \mathrm{~mL}$ of PBS containing 3\% serum and resuspended in $500 \mu \mathrm{L}$ of $3 \%$ serum/PBS. HBc-siNEG-coated beads were analyzed by flow cytometry using a BD FACS Calibur flow cytometer (BD Biosciences, USA). A total of 100000 events were gated, and fluorescence was analyzed in triplicate by detecting Alexa Fluor 488 and Atto-655 fluorescence using FL-1 and FL-4 channel detector, respectively, and BD CellQuest software (BD Biosciences, USA). The median fluorescence intensity (MFI) of the beads is directly proportional to siNEG $\mathrm{Atto655}_{5}$ loaded in $\mathrm{Z}_{\mathrm{HER2}}-\Delta \mathrm{HBc}_{\mathrm{AF} 480}$.

2.5. In Vitro siRNA Stability in Serum. The degree of enzymatic degradation induced by serum nucleases was studied by an incubation of noncoding siRNA (siNEG) encapsulated within $\mathrm{HBc}$ particles with fetal bovine serum (FBS). The HBc-siNEG hybrid particles at $\mathrm{HBc} /$ siNEG molar ratio 1:1 (ratio at which complete siRNA encapsulation was achieved) were prepared using method III (found to be the most efficient encapsulation method) as described above. After complexes were formed, FBS was then added to the complexes at a final concentration of $50 \% \mathrm{v} / \mathrm{v}$, and samples were incubated at $37^{\circ} \mathrm{C}$ for 0 , 24 , or $48 \mathrm{~h}$. After incubation, the reaction was stopped by adding EDTA to a final concentration of $10 \mathrm{mM}$. Nonincubated and coincubated naked siNEG with FBS and EDTA were used as positive and negative controls, respectively. Samples were subjected to a gel retardation assay ( $2 \%$ agarose gel, $100 \mathrm{~V}, 30 \mathrm{~min}$, GelRed $0.005 \% \mathrm{v} /$ v). Gel was then imaged under UV light using ChemiDocMP system (Bio-Rad Laboratories, USA).

2.6. In Vitro siRNA Protection against RNase. The hybrid particles at $\mathrm{HBc} / \mathrm{siNEG}$ molar ratio 1:1 were prepared using method III as described above. After forming the complexes, RNase A was added to the complexes at a final concentration of $6.6 \mu \mathrm{g} / \mathrm{mL}$. Samples were then incubated at $37{ }^{\circ} \mathrm{C}$ for 0,24 , or $48 \mathrm{~h}$. After incubation, the reaction was stopped by adding EDTA to a final concentration of $50 \mathrm{mM}$. Naked siNEG $(0.25 \mu \mathrm{g})$ nonincubated and co-incubated with FBS and EDTA were used as positive and negative controls, respectively. Samples were subjected to a gel retardation assay ( $2 \%$ agarose gel, $100 \mathrm{~V} 30 \mathrm{~min}$, GelRed $0.005 \% \mathrm{v} / \mathrm{v}$ ). Gel was then imaged under UV light using ChemiDocMP system (Bio-Rad Laboratories, USA).

2.7. Cell Culture. HER2-positive cells $\left(\mathrm{HER} 2^{+}\right)$, MDA-MB-435MLE and SKBR-3 cells, and HER2-negative (HER2 ${ }^{-}$) MDA-MB-468 cells were selected in the present study. Their HER2 expression level was confirmed previously. ${ }^{20}$ MDA-MB-435-MLE cells (human melanoma in origin) were obtained by transfecting MDA-MB-435 cells (ATCC, HTB-129) with MUC1, luciferase, and ErbB2 genes as previously reported. ${ }^{28}$ MDA-MB-435-MLE cells were cultured in DMEM media; MDA-MB-468 human breast adenocarcinoma (ATCC, HTB-132) and SKBR-3 human breast carcinoma (ATCC, HTB-30) were cultured in advanced RPMI media. All culture media were supplemented with $10 \% \mathrm{FBS}, 50 \mathrm{U} / \mathrm{mL}$ penicillin, $50 \mu \mathrm{g} / \mathrm{mL}$ streptomycin, and $1 \% \mathrm{~L}$-glutamine at $37{ }^{\circ} \mathrm{C}$ in $5 \% \mathrm{CO}_{2}$. All cells were routinely grown in $75 \mathrm{~cm}^{2}$ canted-neck tissue culture flasks and passaged twice a week using Trypsin/EDTA at $80 \%$ confluency.

2.8. In Vitro Cell Uptake Studies of $\mathrm{HBc}-$ siRNA Hybrid

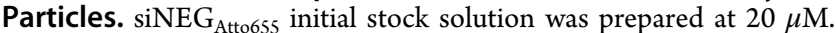
Prior to in vitro cell uptake, siRNA complex preparations were carried out as follows: $1.0 \mu \mathrm{g}(250 \mu \mathrm{L})$ of siNEG $\mathrm{Atto655}_{\text {in }}$ 5\% dextrose was mixed with an equal volume of Lipofectamine2000 $(4.0 \mu \mathrm{g})$ in $5 \%$ dextrose at 4:1 nitrogen $(\mathrm{N}) /$ phosphate (P) charge ratio. $\Delta \mathrm{HBc}_{\mathrm{AF} 488}-$ or $\mathrm{Z}_{\mathrm{HER2}}-\Delta \mathrm{HBc}_{\mathrm{AF} 488}-$ siNEG ${ }_{\mathrm{Atto655}}$ hybrid particles were prepared using method III (found to be the most efficient encapsulation method) at 1:1 $\mathrm{HBc} /$ siNEG molar ratio (containing $480 \mu \mathrm{g}$ of $\mathrm{HBc}$ and $1.0 \mu \mathrm{g}$ of siNEG), buffer-exchanged to $1 \times \mathrm{PBS}$, to maintain isotonicity, and concentrated to $500 \mu \mathrm{L}$ final volume using Vivaspin MWCO $10 \mathrm{kDa}$. MDA-MB-468 (HER2 ${ }^{-}$) and SKBR-3 $\left(\right.$ HER2 $\left.^{+++}\right)$cells were seeded at a density of $1 \times 10^{5}$ cells/well in 24well plates and allowed to attach overnight. After washing with PBS buffer, cells were then treated with naked siNEG ${ }_{\mathrm{Atto655}}$, Lipofectamine-siNEG $\mathrm{Atto655}_{5}$ complexes, or $\Delta \mathrm{HBc}_{\mathrm{AF} 488}-\mathrm{siNEG} \mathrm{Atto655}$ or $\mathrm{Z}_{\mathrm{HER}^{-}}$ $\triangle \mathrm{HBc}_{\mathrm{AF} 488}-$ siNEG $_{\mathrm{Atto655}}$ hybrid particles in serum-free media for 1,4 , or $24 \mathrm{~h}$. For $24 \mathrm{~h}$ treatment, after $4 \mathrm{~h}$ incubation with the hybrids, FBS was added to each well to reach final FBS concentration of $10 \% \mathrm{v} / \mathrm{v}$, and incubated for another $20 \mathrm{~h}$. At the end of incubation period, cells were washed twice with PBS buffer, trypsinized, and centrifuged at 50 $\mathrm{g}$ for $5 \mathrm{~min}$, and the cell pellet was resuspended in $250 \mu \mathrm{L}$ of PBS buffer. The internalization of $\mathrm{HBc}-$ siNEG hybrid particles $_{\text {Atto6s5 }}$ and

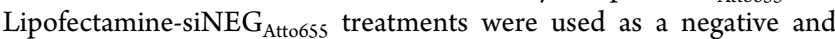
positive control, respectively. The data were analyzed using $\mathrm{BD}$ CellQuest software (BD Biosciences, USA). The effects of the presence of serum on the $\mathrm{HBc}-$ siRNA hybrid particle uptake were examined by performing the same treatments described above in complete serum-containing media for 1 or $24 \mathrm{~h}$.

2.9. In Vitro Cytotoxicity Studies of $\mathrm{HBc}-$ siRNA Hybrid Particles. MDA-MB-468 $\left(\right.$ HER2 $\left.^{-}\right)$or SKBR-3 $\left(\right.$HER2 $\left.^{+}\right)$cells were seeded at a density of $5 \times 10^{3}$ cells/well in 96-well plates and allowed to attach overnight at $5 \% \mathrm{CO}_{2}$ and $95 \%$ air at $37{ }^{\circ} \mathrm{C}$. After washing with PBS buffer, cells were treated with lipoplexes (siNEG or siPLK1 complexed with Lipofectamine2000 (4:1 N/P ratio)), $\Delta \mathrm{HBc}-$ siNEG, $\Delta \mathrm{HBc}-$ siPLK1, $\mathrm{Z}_{\mathrm{HER} 2}-\Delta \mathrm{HBc}-\mathrm{siNEG}$, or $\mathrm{Z}_{\mathrm{HER} 2}-\Delta \mathrm{HBc}-\mathrm{siPLK} 1$, all at 1:1 HBc/siRNA molar ratio, containing increasing concentrations of siRNA at 5, 10, or $20 \mathrm{nM}$ in serum-free media for $4 \mathrm{~h}$. After $4 \mathrm{~h}$, the formulation was discarded, cells were washed with PBS buffer, complete medium was added, and cells were incubated for another 68 h. Cell viability was examined by MTT (3-(4, 5-dimethylthiazol-2-yl)2,5-diphenyltetrazolium bromide) assay. Briefly, the medium from each well was removed after $72 \mathrm{~h}$ incubation and replaced with 120 $\mu \mathrm{L}$ of MTT solution (at a concentration of $5 \mathrm{mg} / \mathrm{mL}$ in PBS with a further 1:6 dilutions in media prior to use). Cells were incubated for 3 $\mathrm{h}$ in $5 \% \mathrm{CO}_{2}$ and $95 \%$ air at $37{ }^{\circ} \mathrm{C}$. Solution was discarded, and formazan was then solubilized in $200 \mu \mathrm{L}$ of DMSO. The absorbance was read at $570 \mathrm{~nm}\left(A_{570 \mathrm{~nm}}\right)$ using a FLUOstar OPTIMA plate reader (BMG Labtech, Germany).

The effects of serum on the HBc-siRNA hybrid particle cytotoxicity were examined by treating cells with the same complexes and conditions mentioned above but in complete media instead. Cell viability was examined by MTT assay as described previously.

2.10. In Vitro PLK1 Gene Silencing in HER2+ Cells. SKBR-3 and MDA-MB-435-MLE cells were seeded at a density of $5 \times 10^{5}$ cells/well in 6-well plates and allowed to attach overnight at $5 \% \mathrm{CO}_{2}$ and $95 \%$ air at $37{ }^{\circ} \mathrm{C}$. After washing with PBS buffer, cells were then treated with lipoplexes (siNEG or siPLK1 complexed with Lipofectamine2000 (4:1 N/P ratio)) or $\mathrm{Z}_{\mathrm{HER} 2}-\Delta \mathrm{HBc}-$ siNEG or $\mathrm{Z}_{\mathrm{HER} 2^{-}}$ $\triangle \mathrm{HBc}-$ siPLK1 at 1:1 $\mathrm{HBc} / \mathrm{siRNA}$ molar ratio containing $20 \mathrm{nM}$ siRNA in serum-free media for $4 \mathrm{~h}$, and then serum was added to the treatment at a final concentration of $10 \% \mathrm{v} / \mathrm{v}$, and cells were incubated for another 20 or $44 \mathrm{~h}$. After 24 or $48 \mathrm{~h}$ post-transfection, cells were washed twice with ice-cold PBS buffer before lysis. Lysates were examined by Western Blotting analysis to determine the level of PLK1 expression (as described in section 2.15). 
A
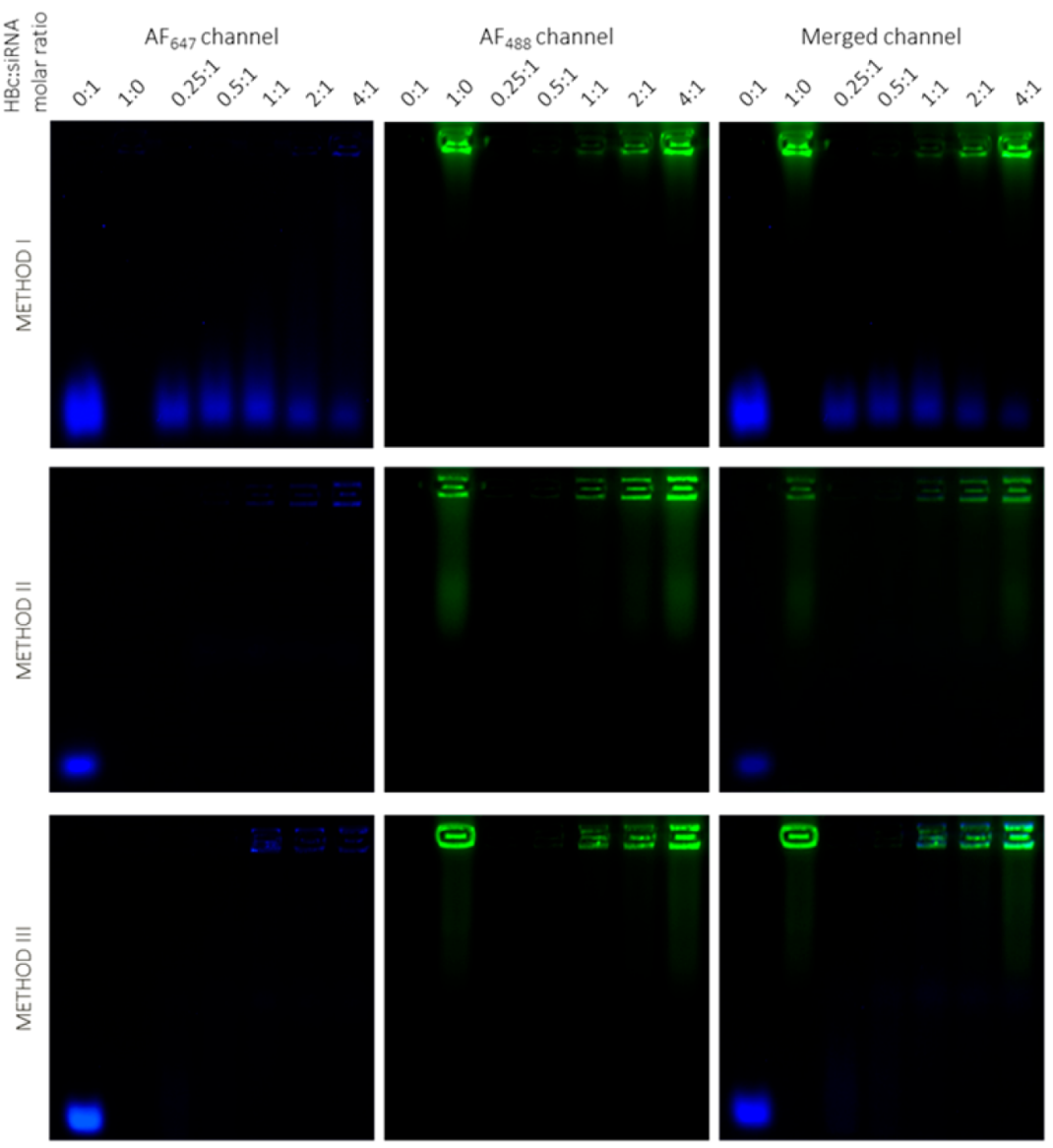

B

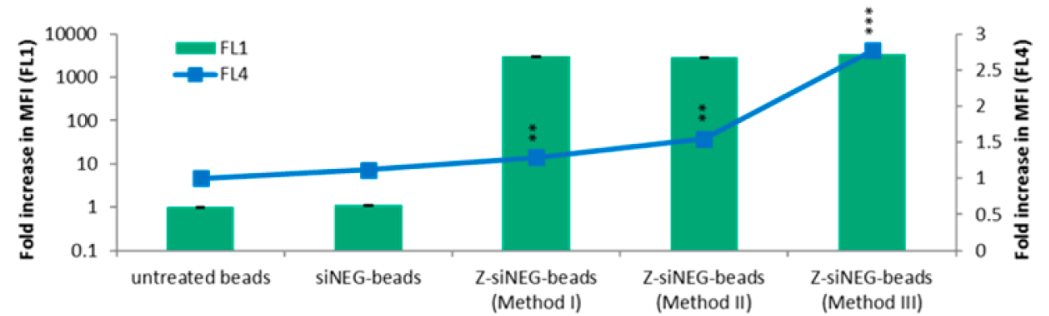

Figure 1. Encapsulation of siRNA with $\mathrm{HBc}$ particles at various $\mathrm{HBc} / \mathrm{siNEG}$ molar ratios using three different methods. (A) Fluorescently labeled nonfunctional siRNA ( siNEG $_{\text {Atto655 }}$ ) (blue) was encapsulated with various amounts of fluorescently labeled $\mathrm{Z}_{\mathrm{HER2}}-\Delta \mathrm{HBc}\left(\mathrm{Z}_{\mathrm{HER2}}-\Delta \mathrm{HBc} \mathrm{AF488}\right)$ particles (green), at $\mathrm{HBc} / \mathrm{siNEG}$ molar ratio of 0 to 4 , using three different methods, before performing the gel retardation assay. In method I, siRNA encapsulation efficiency was increased with increasing molar ratios, with partial amount of free siRNA still being observed at molar ratio 4:1. In methods II and III, siRNA encapsulation efficiency was increased with increasing molar ratios, with complete encapsulation observed at molar ratio 4:1 and 1:1, respectively. (B) Aldehyde sulfate latex beads were coupled with 1:1 molar ratio HBc-siNEG hybrid particles, encapsulated using

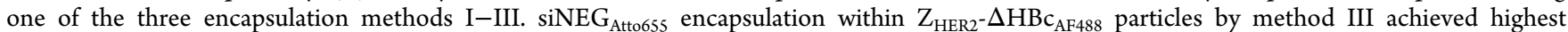
encapsulation efficiency, indicated by the fold increase of median fluorescence intensity (MFI) in FL4 channel. $* * p<0.01, * * * p<0.001$, relative to untreated beads (one-way ANOVA test).

2.11. Animal Studies and Tumor Inoculation. All animal experiments were performed in compliance with the UK Home Office (1989) Code of Practice for the housing and care of Animals used in Scientific Procedures. MDA-MB-435-MLE cells (HER2 ${ }^{+}$) were used as the in vivo tumor model. Male NSG mice aged 4-6 weeks (Charles River, UK) were injected intraperitoneally with MDA-MB-435-MLE cells $\left(5.0 \times 10^{6}\right.$ cells in $\left.100 \mu \mathrm{L} \mathrm{PBS}\right)$, and tumor progression was observed by whole body bioluminescence imaging using IVIS Lumina series III In Vivo Imaging Device (IVIS) (Caliper Life Sciences, PerkinElmer, USA). In each imaging session, mice were administered D-luciferin at $150 \mathrm{mg} / \mathrm{kg}$ subcutaneously. Animals were visualized at 12 min postluciferin injection to ensure consistent photon flux and analyzed using Living Image software (Caliper Life Sciences,
PerkinElmer, USA). Photon flux from the tumor is proportional to the number of live cells expressing luciferase.

2.12. Therapy Study. On day 4 post-tumor inoculation, NSG mice were divided into 4 treatment groups $(n=7)$ : PBS, $\mathrm{Z}_{\mathrm{HER} 2}$ $\Delta \mathrm{HBc}-$ siNEG, $\Delta \mathrm{HBc}-$ siPLK1, and $\mathrm{Z}_{\mathrm{HER} 2}-\Delta \mathrm{HBc}-$ siPLK1 treatment. Doses used in therapy experiments were $4 \mu \mathrm{g}$ of siNEG or siPLK1 per injection per mouse; all treatments were injected intraperitoneally. A total of seven doses of each treatment were given at 3 day intervals on days $4,7,10,13,16,19$, and 22 post-tumor inoculation. Tumor growth was observed by bioluminescence imaging twice weekly (days 4, 7, 11, 14, 18, 21, and 25), as described above. Mice were sacrificed on day 28 . Only solid adherent tumor nodules were excised and weighed, while tumor cells suspended in ascites were discarded. 
A
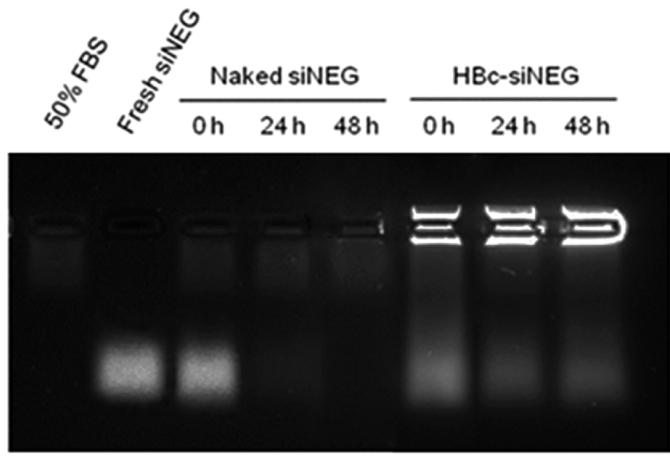

B

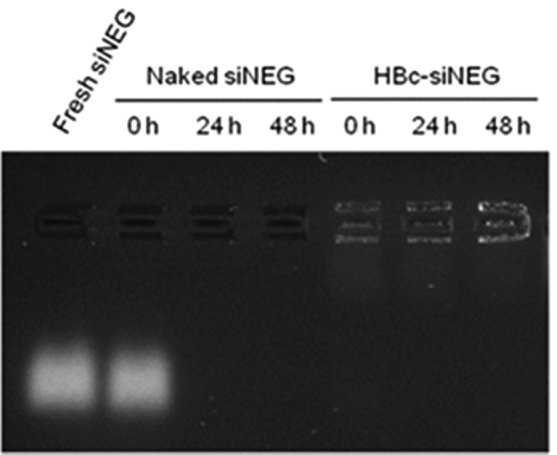

Figure 2. Stability studies of $\mathrm{HBc}-\mathrm{siNEG}$ hybrid particles against serum and RNase. Gel retardation assay for HBc-siNEG hybrid particles subjected to (A) serum; (B) RNase at HBc/siNEG 1:1 molar ratio. The hybrid particles were prepared at a fixed siNEG amount of $0.25 \mu$ g. $\mathrm{HBc}-$ siNEG hybrid particles were incubated with $50 \% \mathrm{v} / \mathrm{v}$ FBS $(0,24$, or $48 \mathrm{~h})$ or RNase $(0,24$, or $48 \mathrm{~h})$ at $37{ }^{\circ} \mathrm{C}$. EDTA was used to inactivate serum proteins.

2.13. Determination of TNF- $\alpha$ Concentration with ELISA. Animals from the therapy study were sacrificed on day 28 (6 days after the last injection), and sera was analyzed for mouse tumor necrosis factor $\alpha$ (TNF- $\alpha$ ). A separate group of tumor-bearing mice was injected with lipopolysaccharide (LPS, $3 \mathrm{mg} / \mathrm{kg}$ ) intraperitoneally, and their sera were collected $1 \mathrm{~h}$ postinjection as positive controls. Sera were diluted 1:2 using $1 \times \mathrm{PBS}$ and analyzed using a BD OptEIA Mouse TNF (Mono/Mono) ELISA set as per the manufacturer's protocol.

2.14. Organ Histology. Major organs (heart, lung, liver, spleen, and kidney) and tumors were harvested and immediately fixed in $10 \%$ neutral buffered formalin at $5 \mathrm{~mm}^{2}$ pieces. Tissue pieces were paraffinembedded and sectioned for hematoxylin and eosin (H\&E) staining according to the standard histological protocols at the Royal Veterinary College, U.K. The stained sections were analyzed with a Leica DM 1000 LED Microscope (Leica Microsystems, U.K.) coupled with CDD digital camera (QImaging, U.K.).

2.15. Gene Silencing Evaluation by Western Blot. For in vitro studies, cells were collected directly into a lysis buffer $(50 \mathrm{mM}$ Tris$\mathrm{HCl}, \mathrm{pH} 8.0,1.0 \%$ Triton X100, $150 \mathrm{mM} \mathrm{NaCl}, 5 \mathrm{mM}$ EDTA) and incubated on ice for $10 \mathrm{~min}$. For in vivo studies, at sacrifice on day 28 , collected tumors were crushed directly into the lysis buffer and incubated on ice for $30 \mathrm{~min}$. Samples were then separated by centrifugation at $20800 \mathrm{~g}$ for $15 \mathrm{~min}$ at $4{ }^{\circ} \mathrm{C}$. After the collection of supernatant, total protein concentration was measured using BCA protein assay kit. A total of $200 \mu \mathrm{g}$ of protein was then taken from each supernatant and separated on 15\% SDS-PAGE gels for electrotransfer onto a nitrocellulose membrane. After blocking in $3 \%$ skimmed milk for overnight, membranes were stripped for PLK1 $(67 \mathrm{kDa})$ and GAPDH $(40 \mathrm{kDa}$, a housekeeping gene (internal reference)) detection separately. For PLK1, membranes were immunoblotted with rabbit monoclonal PLK1 antibody at 1:1000 dilution as primary antibody, followed by HRP-linked anti-rabbit at 1:1000 dilution and Precision Protein StrepTactin-HRP conjugate at 1:10 000 dilution for secondary antibody. For GAPDH, membranes were immunoblotted with mouse anti-GAPDH antibody at 1:1000 dilution (primary antibody), followed by mix of HRP-linked antimouse at 1:1000 dilution (secondary antibody) and Precision Protein StrepTactin-HRP conjugate at 1:10000 dilution. The specific bands were identified using enhanced chemiluminescence (ECL) detection system. The membrane was visualized using the ChemiDocMP (BioRad Laboratories, USA) and analyzed with Image Lab (Bio-Rad Laboratories, USA) software. The quantity of PLK1 transcript was normalized to GAPDH in each sample and correlated to the normalized expression in naive cells to calculate the fold changes.

2.16. Statistics. In all experiments, data were presented as mean \pm SD, where $n$ denotes the number of repeats. Significant differences were determined using one-way ANOVA. The t-value, degrees of freedom, and two-tailed significance ( $p$-value) were resolved as $* p<$ $0.05, * * p<0.01$, and $* * * p<0.001$.

\section{RESULTS}

3.1. Disassembly/Reassembly of $\mathrm{HBC}$ Particles by DTT/ $\mathrm{CaCl}_{2}$ (Method III) Is the Most Efficient Method for siRNA Encapsulation with Complete Complexation at 1:1 siRNA to Particle Molar Ratio. The encapsulation of siRNA into $\mathrm{HBc}$ particles was first optimized. The recombinant $\mathrm{Z}_{\mathrm{HER} 2}-\Delta \mathrm{HBC}$ particles were expressed, purified, and assembled. The assembled $\mathrm{Z}_{\mathrm{HER} 2}-\Delta \mathrm{HBc}$ particles were then fluorescently labeled with Alexa Fluor 488 succinimidyl esters $\left(\mathrm{Z}_{\mathrm{HER} 2}-\Delta \mathrm{HBc}_{\mathrm{AF} 480}\right)$ as described previously. ${ }^{20}$ Fluorescently labeled noncoding siRNA ( siNEG $_{\text {Att0655) }}$ ) was encapsulated into $\mathrm{Z}_{\mathrm{HER} 2}-\Delta \mathrm{HBc}_{\mathrm{AF} 480}$ particles using three different methods, disassembly/reassembly by urea (method I), osmotic shock (method II), or disassembly/reassembly by $\mathrm{DTT} / \mathrm{CaCl}_{2}$ (method III), to form $\mathrm{HBc}-$ siRNA hybrid particles; all methods are schematically described as shown in Figure S1. In method I, urea was used as a denaturing agent to weaken the protein-protein interactions between $\mathrm{HBc}$ monomers, thus loosening the particle formation, which is expected to allow the siRNA to penetrate into the $\mathrm{HBc}$ particles. ${ }^{29,30}$ Additionally, the high salt concentration of $\mathrm{NaCl}$ added in the assembly stage is expected to increase the electrostatic repulsion between the protein monomers, promoting the $\mathrm{Z}_{\mathrm{HER} 2}-\Delta \mathrm{HBc}_{\mathrm{AF} 480}$ assembly in an organized manner forming of $\mathrm{HBc}-$ siRNA hybrid particles. ${ }^{31}$ In method II, an osmotic shock was induced to encapsulate siRNA following reported protocols $^{32}$ with some modifications. An osmotic shock or osmotic stress introduced by a sudden change in the solute concentration around the particles is expected to cause the particles' pores to swell up, allowing the entry of the siRNA into the particles. ${ }^{33}$ This method is not expected to cause disassembly of the particles. In method III, $\mathrm{HBc}$ particles were disassembled in the presence of a chelating agent, EGTA, and a reducing agent, DTT. ${ }^{34}$ An EGTA-DTT combination is therefore expected to completely disrupt the $\mathrm{HBc}$ particles; EGTA has high affinity for $\mathrm{Ca}^{2+}$. As the assembly of $\mathrm{HBc}$ particles is highly $\mathrm{Ca}^{2+}$-dependent, $\mathrm{HBc}$ was then reassembled by adding $\mathrm{Ca}^{2+}$ to increase the electrostatic repulsions between the protein monomers. ${ }^{35,36}$ The size of empty $\mathrm{HBc}$ particles was confirmed to be $\sim 30 \mathrm{~nm}^{20}$ 

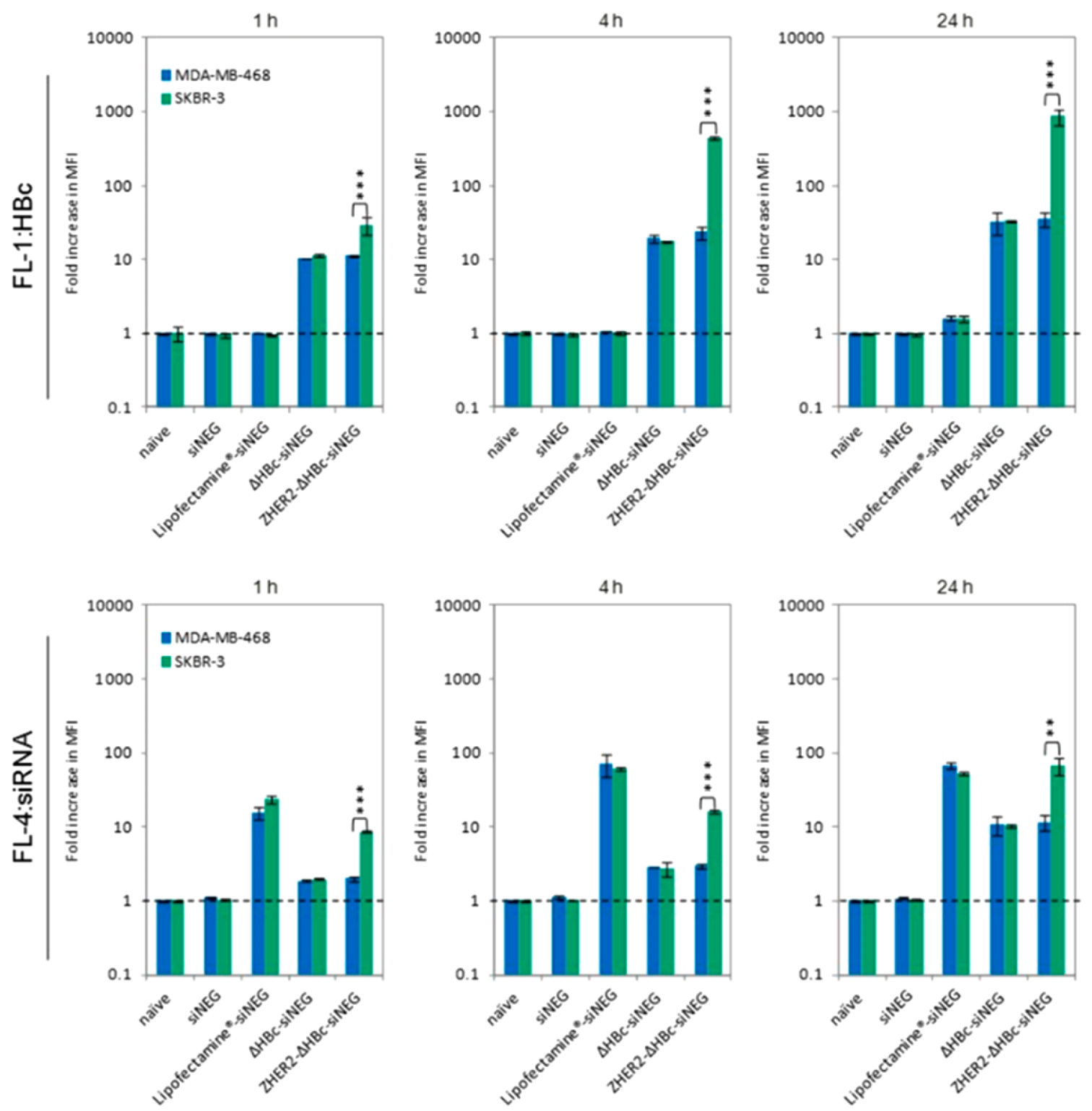

Figure 3. In vitro uptake studies using HBc-siNEG particles in HER2- (MDA-MB-468) and HER2 ${ }^{+++}$(SKBR-3) expressing cancer cells. Fold

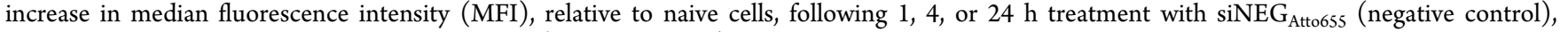

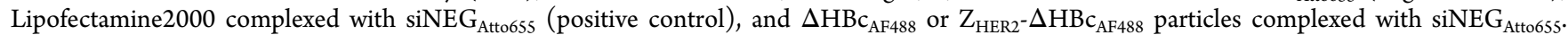
Cellular uptake was assessed using flow cytometry (FL-1, FL-4). A significantly higher siNEG Atto655 $_{5}$ uptake was observed for $\mathrm{Z}_{\mathrm{HER2}}-\Delta \mathrm{HBc}-\mathrm{siNEG}$ particles compared to $\Delta \mathrm{HBc}$-siNEG particles, in a time-dependent manner (FL-1, FL-4). Values are expressed as fold increase in MFI \pm SD $(n=$ 6). $* * p<0.01, * * * p<0.001$, relative to MDA-MB-468 cells (one-way ANOVA test).

The siRNA encapsulation profiles using the three different methods were assessed and compared using gel retardation assay as shown in Figure 1A. The green color is assigned to $\mathrm{HBc}$ while blue color indicates either free or complexed siRNA. Decreasing signals of free siRNA bands (blue color) observed at the bottom of the gel is a sign of complexation. In method I, siRNA encapsulation efficiency was improved with increasing complexation molar ratios of $\mathrm{HBc} / \mathrm{siRNA}$ from 2:1 to $4: 1$. Some free siRNA was still observed even at $4: 1 \mathrm{HBc} /$ siRNA molar ratio. In methods II and III, complete encapsulation was achieved at $\mathrm{HBc} / \mathrm{siRNA}$ molar ratio 4:1 and $1: 1$, respectively. No free siRNA was detected at the bottom of the gel in such conditions with the concomitant observation of increased fluorescence in the wells.

Another technique, the bead coupling assay, schematically presented in Figure S2, was employed to confirm siRNA incorporation into $\mathrm{Z}_{\mathrm{HER} 2}-\Delta \mathrm{HBc}$ particles by flow cytometry using FL-1 (Z- $\left.\Delta \mathrm{HBc}_{\mathrm{AF} 488}\right)$ and FL-4 (siNEG Atto655 $)$ channels. Using this method, siRNA encapsulated using method III showed the highest amount of siRNA encapsulation, compared to method I and method II (Figure 1B). This result is in agreement with the results obtained by gel retardation assay. It was concluded that approximately $1 \mathrm{~mol}$ of siRNA can be encapsulated in $1 \mathrm{~mol}$ of $\mathrm{HBc}$ particles using method III. Method III was used in the subsequent studies.

\subsection{HBc-siRNA Hybrids Are Stable against RNase} and in Serum. The ability of $\mathrm{HBc}-$ siRNA hybrids to protect siNEG from degradation by nuclease was evaluated by challenging the hybrid particles against serum. Naked siNEG and $\mathrm{HBc}-$ siNEG hybrid particles were incubated at $37{ }^{\circ} \mathrm{C}$ in $50 \% \mathrm{v} / \mathrm{v}$ FBS for 0,24 , or $48 \mathrm{~h}$. As shown in Figure 2A, FBS alone exhibited weak signals shown in the middle of the gel 
A

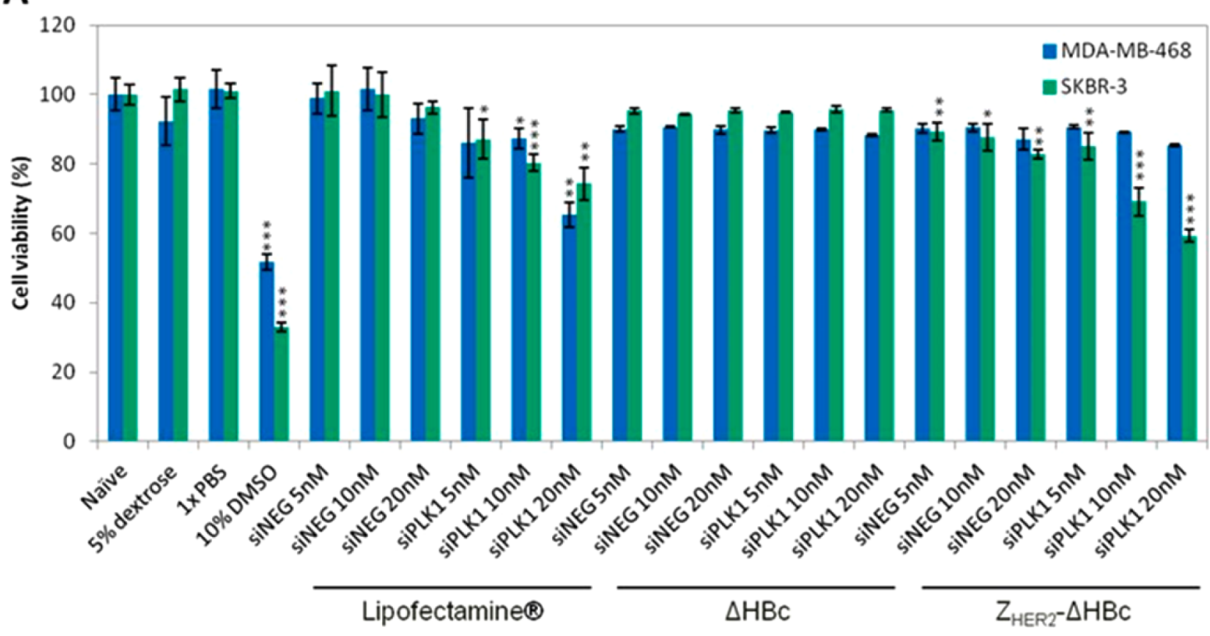

B

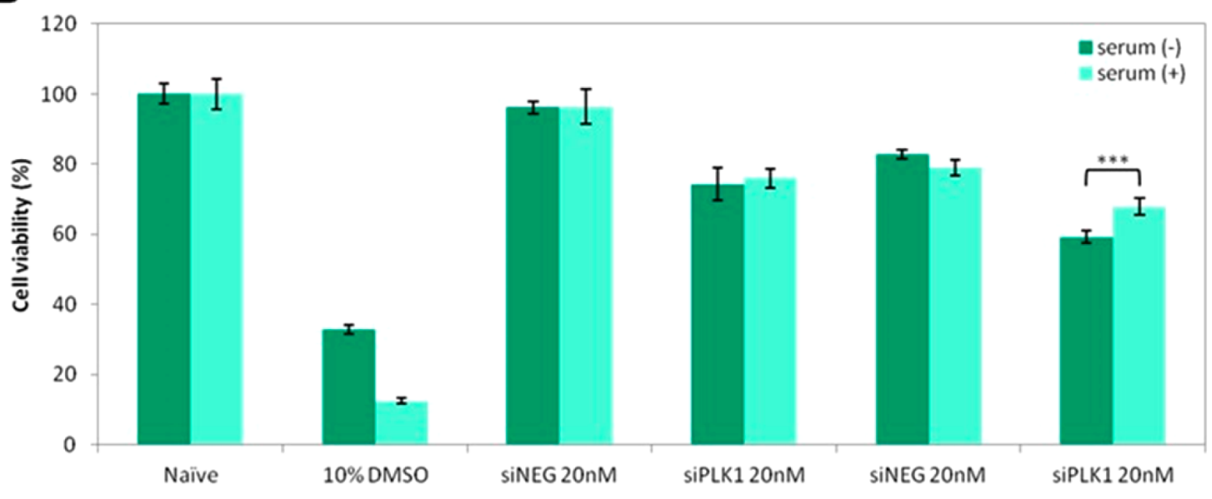

Lipofectamine $^{*}$

$\mathrm{Z}_{\mathrm{HER} 2}-\mathrm{HBC}$

Figure 4. Cell viability of cancer cell lines treated with siRNA-HBc particles in vitro. (A) MDA-MB-468 and SKBR-3 cell lines were treated with siNEG and siPLK1 at increasing concentration $(5,10$, and $20 \mathrm{nM})$ in serum free media for $4 \mathrm{~h}$ followed by incubation in complete media for another $68 \mathrm{~h}$. Treatment groups include 5\% dextrose, 1×PBS, lipoplexes (siNEG or siPLK1 in complex with Lipofectamine2000 (4:1 N/P)), $\Delta \mathrm{HBc}-$ siNEG, $\Delta \mathrm{HBc}-\mathrm{siPLK1}, \mathrm{Z}_{\mathrm{HER} 2}-\Delta \mathrm{HBc}-$ siNEG, or $\mathrm{Z}_{\mathrm{HER} 2}-\Delta \mathrm{HBc}-$ siPLK1, all at 1:1 HBc/siRNA molar ratio. Cell viability was analyzed and expressed as a percentage of naive cells, determined by MTT assay. (B) Percentage cell viability (SKBR-3 cells) after $72 \mathrm{~h}$ transfection $\pm 10 \%$ serum at $20 \mathrm{nM}$ final concentration. Cell viability was analyzed and expressed as a percentage of naive cells, determined by MTT assay. Values are expressed as mean $\pm \mathrm{SD}(n=6) . *_{p}<0.05, * * p<0.01$, ***p $<0.001$, relative to naive (one-way ANOVA test).

(first lane) that are located differently from the signals of either free or encapsulated siNEG occurring at the bottom of the gel or at the wells, respectively, shown in other lanes. After $24 \mathrm{~h}$ incubation with serum, naked siNEG was almost degraded, with complete degradation of siNEG observed at $48 \mathrm{~h}$ incubation.

In contrast, $\mathrm{HBc}-\mathrm{siNEG}$ particles exhibited strong signals for encapsulated siNEG in the well at all time points. Interestingly, free siNEG signals were also present at the bottom of the gel, even at the $0 \mathrm{~h}$ time point, suggesting a partial release of siNEG from the hybrids in the presence of serum. These results suggest that complexation with $\mathrm{HBc}$ particles improves siRNA stability in the presence of serum. The ability of $\mathrm{HBc}-$ siRNA hybrids to protect siRNA against a ribonuclease (RNase) was evaluated by incubating the hybrids with RNase for 0,24 , or $48 \mathrm{~h}$ at $37^{\circ} \mathrm{C}$. As shown in Figure $2 \mathrm{~B}$, naked siRNA was completely degraded after $24 \mathrm{~h}$ incubation with RNase. In contrast, strong signals were observed in the wells of $\mathrm{HBc}-$ siNEG particles even after $48 \mathrm{~h}$ of incubation with the RNase, indicating that the $\mathrm{HBc}$ particles can protect siNEG from enzymatic degradation.
3.3. HER2-Targeting HBc-siRNA Hybrids Are Selectively Taken Up in HER2-Positive Cancer Cells in Vitro. The intracellular uptake of $\mathrm{HBc}-$ siRNA hybrids in MDA-MB468 (HER2 $^{-}$) and SKBR-3 (HER2 ${ }^{+}$) cells was evaluated by flow cytometry via FL-1 $\left(\mathrm{Z}_{\mathrm{HER} 2}-\Delta \mathrm{HBc}_{\mathrm{AF} 488}\right)$ and FL-4

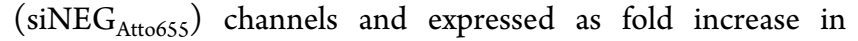
median fluorescent intensity (MFI) (Figure 3). All cells were treated with naked siNEG ${ }_{\text {Atto655, }}$, Lipofectamine-siNEG Atto655 $_{\text {. }}$ complexes, $\Delta \mathrm{HBc}_{\mathrm{AF} 488}-\mathrm{siNEG}_{\mathrm{Atto655}}$ or $\mathrm{Z}_{\mathrm{HER} 2}-\Delta \mathrm{HBc}_{\mathrm{AF} 488}-$ siNEG $\mathrm{Atto655}_{\mathrm{A}}$ hybrids for 1,4 , or $24 \mathrm{~h}$. As shown in Figure 3, treatment of SKBR-3 cells with $\mathrm{Z}_{\mathrm{HER} 2}-\Delta \mathrm{HBc}_{\mathrm{AF} 488}-\mathrm{siNE}$ $\mathrm{G}_{\text {Atto655 }}$ promoted an apparent fold increase at both FL-1 and FL-4 channels in a time-dependent manner (last green bars) in contrast to lower uptake measured for treatments of $\Delta \mathrm{HBc}_{\mathrm{AF} 488}-\mathrm{siNEG} \mathrm{Atto655}$ hybrids in both cells. The trend of

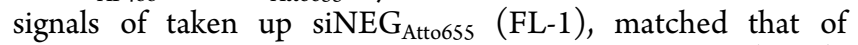
$\Delta \mathrm{HBc}_{\mathrm{AF} 488}$ and $\mathrm{Z}_{\mathrm{HER} 2}-\Delta \mathrm{HBc}_{\mathrm{AF} 488}$ from complexes (FL-4). Taken together, these results indicate that $\mathrm{HBc}-$ siRNA hybrid particles were able to deliver siRNA into the cells in vitro, with

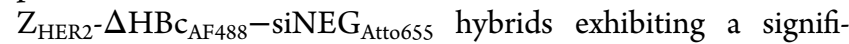
cantly higher uptake profile than $\Delta \mathrm{HBc}_{\mathrm{AF} 488}-\mathrm{siNEG}_{\mathrm{Atto655}}$ 

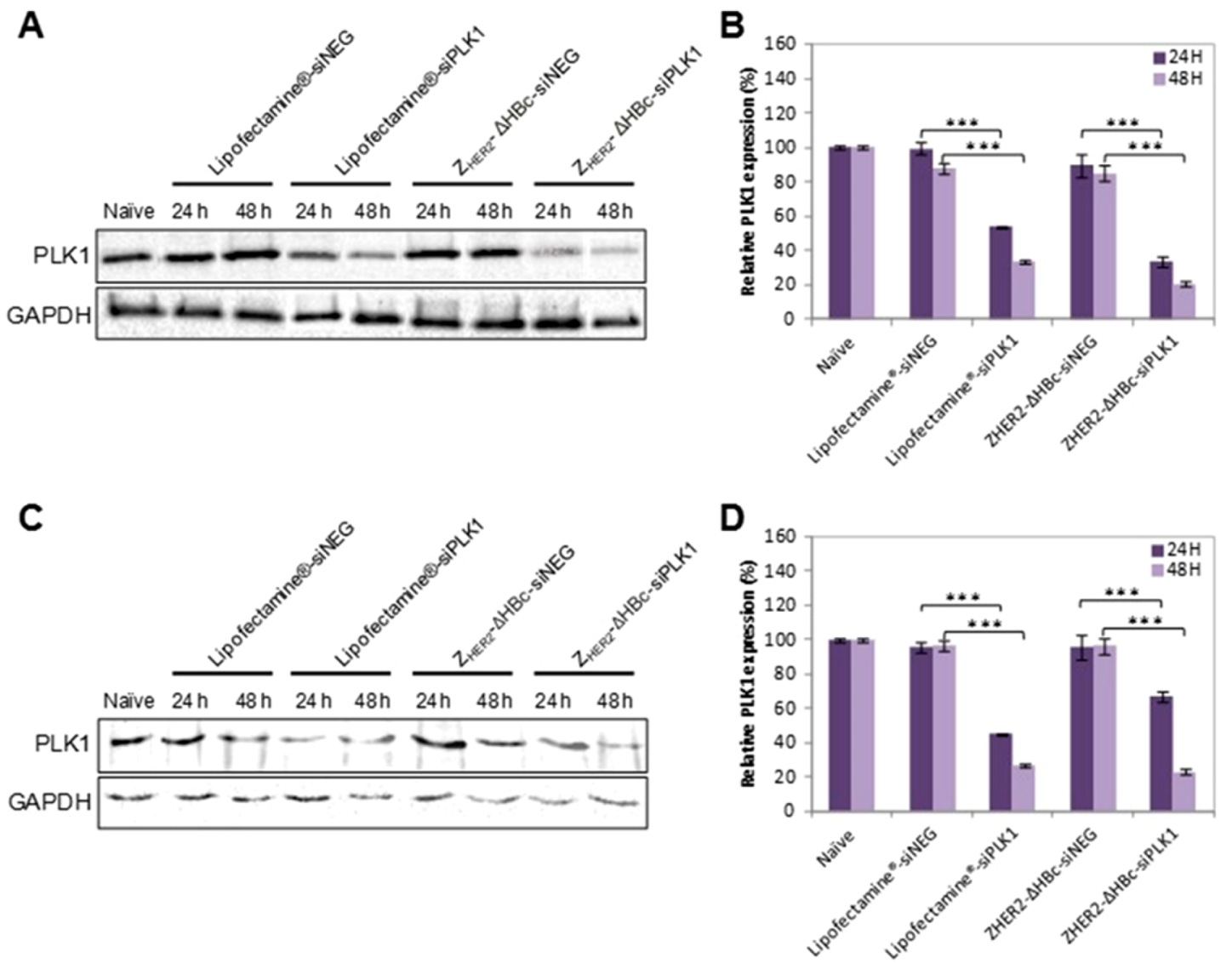

Figure 5. PLK1 gene silencing in HER2 ${ }^{+++}$cancer cells by Western blotting. (A, C) Western blots and (B, D) quantitative analysis of PLK1 expression in (A, B) SKBR-3 and (C, D) MDA-MB-435-MLE cell lines. Treatment groups including lipoplexes (siNEG or siPLK1 in complex with Lipofectamine2000 $(4: 1 \mathrm{~N} / \mathrm{P}))$ and $\mathrm{Z}_{\mathrm{HER} 2}-\Delta \mathrm{HBc}-$ siNEG and $\mathrm{Z}_{\mathrm{HER} 2}-\Delta \mathrm{HBc}-$ siPLK1 at $1: 1 \mathrm{HBc} /$ siRNA molar ratio and $20 \mathrm{nM}$ siRNA concentration. GAPDH gene was used as a housekeeping gene (internal control). An efficient siPLK1 knock-down was achieved with lipoplexes and $\mathrm{Z}_{\mathrm{HER} 2}-\Delta \mathrm{HBc}-$ siPLK1 hybrids. $* * * p<0.001$, relative to groups of siNEG (one-way ANOVA test).

hybrids in HER2 ${ }^{+}$SKBR-3 cells. The intracellular uptake of $\mathrm{HBc}-$ siRNA hybrid particles in vitro was also studied in the presence of serum. Results suggested that the presence of serum slightly but significantly reduced the uptake of the hybrids overall (FL-1, FL-4) in both cell types (Figure S3).

3.4. HER2-Targeting HBc-siPLK1 Hybrids Are Functionally Active in Vitro in the Presence or Absence of Serum. The cytotoxic effect of $\mathrm{HBc}-$ siRNA hybrids was assessed in MDA-MB-468 (HER2 ${ }^{-}$) and SKBR-3 (HER2 ${ }^{+}$) cells in vitro. Nonfunctional siNEG was replaced with functional siRNA specific to PLK1 gene (siPLK1), in order to assess the gene-silencing efficacy. Cells were treated with 5, 10 , or $20 \mathrm{nM}$ siNEG or siPLK1 encapsulated in nontargeted $\Delta \mathrm{HBc}$ or targeted $\mathrm{Z}_{\mathrm{HER} 2}-\Delta \mathrm{HBc}$ particles for $72 \mathrm{~h}$, and cell viability was determined by MTT assay. Lipofectamine2000siPLK1 complexes were used as a positive control (Figure 4A). As expected, cells treated with $\triangle \mathrm{HBc}-$ siPLK1 showed no significant toxicity in both cell lines. These results are in agreement with those obtained for intracellular uptake studies for $\triangle \mathrm{HBc}$ particles alone as these particles lose their nonspecific binding due to lack of the arginine-rich domain. ${ }^{20} \mathrm{~A}$ significant dose-dependent reduction in cell viability was observed for Lipofectamine2000-siPLK1 in both cell lines. Treatments with $\triangle \mathrm{HBc}-$ siPLK1 did not cause significant cytotoxicity in both cell lines. In contrast, treatments with $\mathrm{Z}_{\mathrm{HER} 2}-\Delta \mathrm{HBc}-\mathrm{siPLK} 1$ induced $30-40 \%$ cell death in SKBR-3 cells but not MDA-MB-468 cells. Interestingly, when SKBR-3 cells were treated with $\mathrm{Z}_{\mathrm{HER} 2}-\Delta \mathrm{HBc}-\mathrm{siNEG}$, a significant amount, approximately $10 \%$, cell death was observed. This could be due to some intrinsic toxicity exhibited by $\mathrm{Z}_{\mathrm{HER} 2^{-}}$ $\triangle \mathrm{HBc}$, due to the presence of the affibody, that is, HER2 receptor blockade activity, since such toxicity was not observed when $\triangle \mathrm{HBc}$ hybrids were tested under same conditions.

The cytotoxic effect of $\mathrm{HBc}-$ siRNA hybrids in $\mathrm{HER}^{+}$cells was further studied with subjection to serum competition. Cell viability of SKBR-3 cells treated with $20 \mathrm{nM}$ of siNEG or siPLK1 encapsulated in $\mathrm{Z}_{\mathrm{HER} 2}-\Delta \mathrm{HBc}$ particles was assessed by MTT assay at $72 \mathrm{~h}$ postincubation. Lipofectamine2000siPLK1 complexes were used as a positive control (Figure 4B). Similar reduction in cell viability was seen for cells treated with Lipofectamine2000-siPLK1 regardless of the presence of serum. A slight reduction in cytotoxicity was observed for $\mathrm{Z}_{\mathrm{HER} 2}-\Delta \mathrm{HBc}-\mathrm{siPLK} 1$ in the presence of serum $(* * * p<$ $0.001)$, but this was significantly lower than equivalent siNEG group.

3.5. Efficient PLK1 Knock-down Is Confirmed in Vitro by Western Blotting. To confirm if the reduction in cell viability in the case of $\mathrm{Z}_{\mathrm{HER} 2}-\Delta \mathrm{HBc}-$ siPLK1 hybrid treatment was associated with PLK1 gene silencing, the levels of PLK1 protein expression in vitro were examined using Western blotting. HER2 ${ }^{+}$cells, SKBR-3 and MDA-MB-435-MLE cells, were incubated with $\mathrm{Z}_{\mathrm{HER} 2}-\Delta \mathrm{HBc}-$ siPLK1 hybrids for 24 or $48 \mathrm{~h}$. GAPDH, a housekeeping gene, was used as an internal control. Lipofectamine2000-siPLK1 complexes were included 
A

Day 21

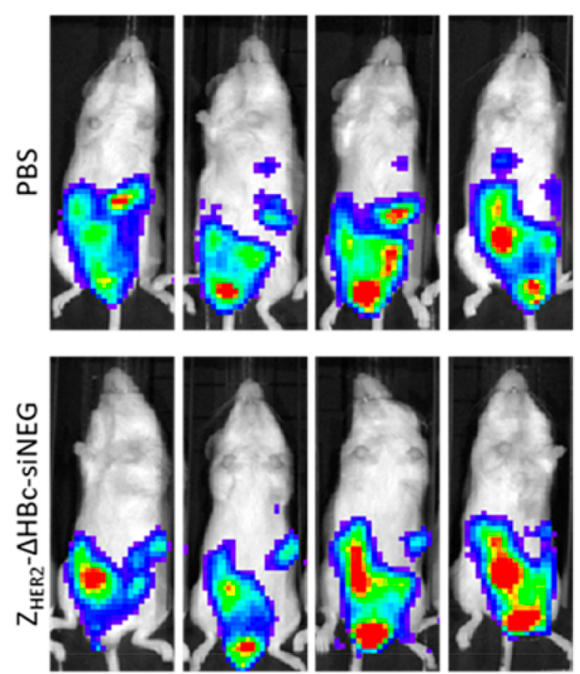

B

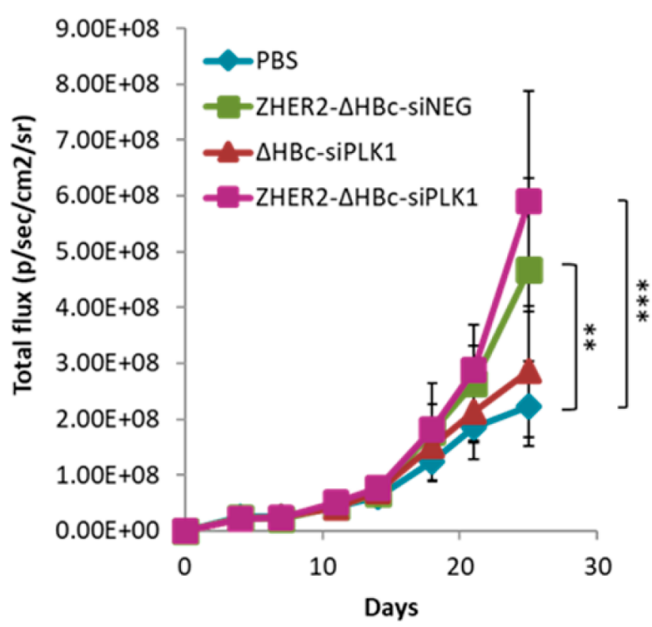

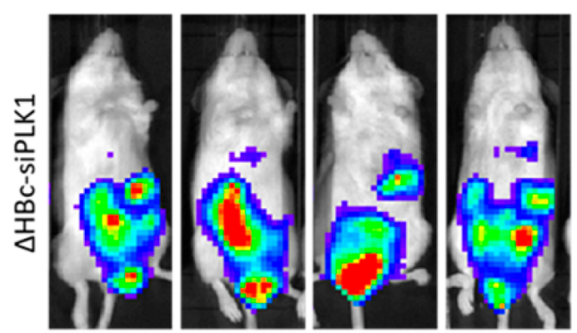

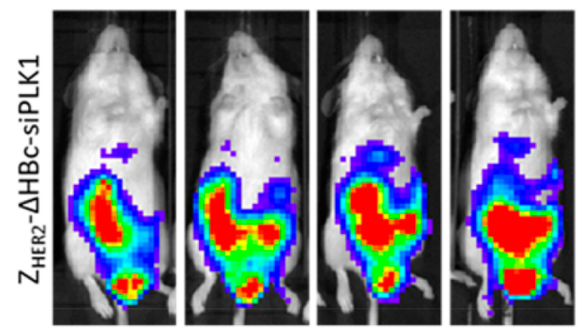

C

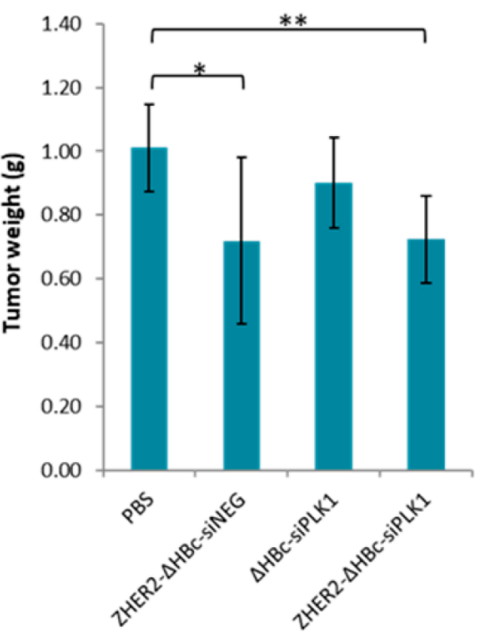

Figure 6. Assessment of tumor bioluminescence and solid weight tumors in HER2-expressing intraperitoneal tumor mouse models. NSG mice $(n=$ 7) were intraperitoneally injected with $5.0 \times 10^{6} \mathrm{MDA}-\mathrm{MB}-435-\mathrm{MLE}$ cells. Mice were treated with PBS, $\mathrm{Z}_{\mathrm{HER} 2}-\Delta \mathrm{HBc}-\mathrm{siNEG}(4 \mu \mathrm{g}$ of siNEG per injection per mouse), $\Delta \mathrm{HBc}-\operatorname{siPLK} 1$ ( $4 \mu \mathrm{g}$ of siPLK1 per injection per mouse) and $\mathrm{Z}_{\mathrm{HER} 2}-\Delta \mathrm{HBc}-\mathrm{siPLK} 1$ ( $4 \mu \mathrm{g}$ of siPLK1 per mouse), intraperitoneally. Seven treatments were given intraperitoneally at 3 day intervals, commencing on day 4 post-tumor inoculation. Tumor growth was observed by whole body imaging. (A) Representative images for in vivo bioluminescent imaging are shown. (B) Growth curves of MDA-MB435-MLE tumors. (C) Weight of tumors excised from mice after sacrifice. Data expressed as mean $\pm \mathrm{SD}(n=7)$. $* p<0.05$, $* * p<0.01, * * * p<$ 0.001 , relative to group of PBS (one-way ANOVA test).

as a control transfecting agent. There was a clear difference in gene silencing efficacy between the two vectors in SKBR-3 cells, where $\mathrm{Z}_{\mathrm{HER} 2}-\Delta \mathrm{HBc}-$ siPLK1 hybrids showed more efficient PLK1 gene knockdown than Lipofectamine2000siPLK1 complexes as measured by PLK1 protein level (Figure $5 \mathrm{~A}, \mathrm{~B})$. In the case of $\mathrm{Z}_{\mathrm{HER} 2}-\Delta \mathrm{HBc}-\mathrm{siPLK1}$ hybrids transfection, PLK1 expression was reduced to $33.4 \% \pm 1.5 \%$ and $20.4 \% \pm 0.6 \%$ at 24 and $48 \mathrm{~h}$ post incubation, respectively, compared to naive cells. In the case of Lipofectamine2000siPLK1 complexes, the protein levels were $53.6 \% \pm 0.5 \%$ and $33.0 \% \pm 1.0 \%$ after the same incubation times $(* * * p<0.001)$ (Figure 5B).

In comparison, incubation with Lipofectamine2000-siPLK1 complexes resulted in a better PLK1 gene knockdown than $\mathrm{Z}_{\text {HER2 }}-\Delta \mathrm{HBc}-$ siPLK1 hybrids after $24 \mathrm{~h}$ in MDA-MB-435MLE cells $(45.4 \% \pm 2.2 \%$ vs $66.9 \% \pm 1.3 \%$, Figure $5 \mathrm{C}, \mathrm{D}$; $* * * p<0.001)$. However, $\mathrm{Z}_{\mathrm{HER} 2}-\Delta \mathrm{HBc}-$ siPLK1 hybrids showed better PLK1 gene knockdown after $48 \mathrm{~h}$, where protein expression was reduced to $23.4 \% \pm 0.5 \%$, compared to only $26.7 \% \pm 0.6 \%$ in the case of Lipofectamine $2000-$ siPLK1 transfection $(* p<0.01)$ (Figure $5 \mathrm{D})$. The results overall indicated that more potent in vitro gene silencing could be achieved using the $\mathrm{Z}_{\mathrm{HER} 2}-\Delta \mathrm{HBc}-$ siPLK1 hybrids than Lipofectamine2000-siPLK1 in cell models tested.

3.6. $\mathrm{Z}_{\mathrm{HER2}}-\Delta \mathrm{HBC}$ and Not siPLK1 Treatment Results in Reduction in Intraperitoneal Solid Tumor Mass in Mice. Representative in vivo bioluminescent images for all treatments on day 21 post-tumor inoculation is shown in Figure 6A. Quantitative analysis of bioluminescence signals from mice whole body is illustrated in Figure 6B. No significant differences in bioluminescence signals were observed between PBS and $\triangle \mathrm{HBC}-$ siPLK1 treatments. Unexpectedly, significantly higher signals were obtained on day 25 in groups receiving $\mathrm{Z}_{\mathrm{HER} 2}-\Delta \mathrm{HBc}-\mathrm{siNEG}(* * p<0.01)$ and $\mathrm{Z}_{\mathrm{HER} 2}{ }^{-}$ 


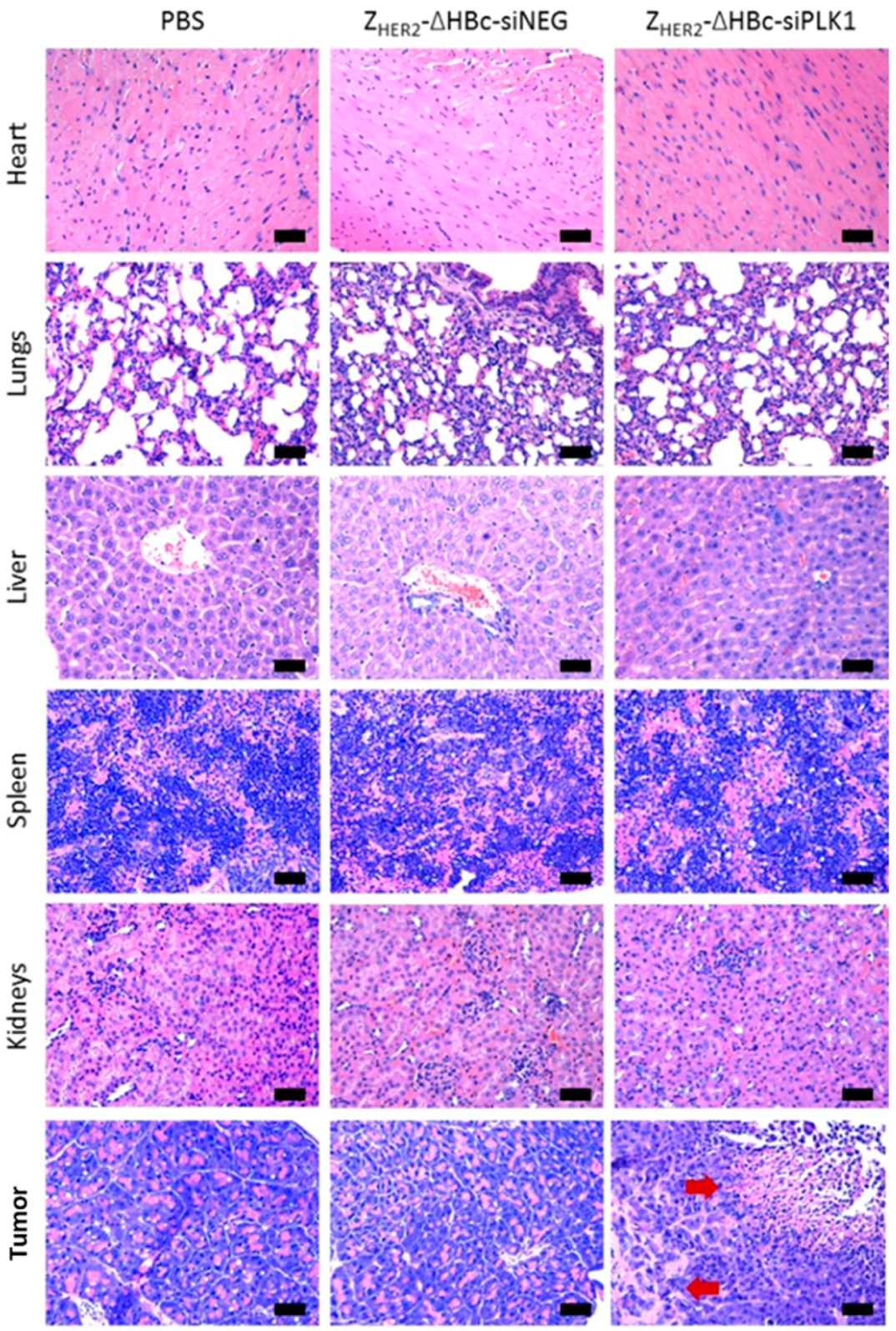

Figure 7. Microscopic examination of major organs and tumor sections of MDA-MB-435-MLE tumor-bearing NSG mice. Mice were treated with PBS, $\mathrm{Z}_{\mathrm{HER} 2}-\Delta \mathrm{HBc}-$ siNEG ( $4 \mu \mathrm{g}$ of siNEG/mouse), $\Delta \mathrm{HBc}-$ siPLK1 $\left(4 \mu \mathrm{g}\right.$ of siPLK1/mouse), and $\mathrm{Z}_{\mathrm{HER} 2}-\Delta \mathrm{HBc}-\mathrm{siPLK} 1$ (4 $\mu \mathrm{g}$ of siPLK1/ mouse), intraperitoneally. Seven treatments were given intraperitoneally at 3 day intervals, commencing on day 4 post-tumor inoculation. At day 28, the mice were sacrificed, and the organs were immediately fixed in $10 \%$ neutral buffer formalin as $5 \mathrm{~mm}^{3}$ pieces. These pieces were then paraffin-embedded for hematoxylin and eosin stains (H\&E) and analyzed by microscopy. No signs of toxicity were observed in heart, lungs, liver, spleen, and kidneys. Red arrows point to the necrotic area in tumor section (pinkish area). Scale bars are $50 \mu \mathrm{m}$.

$\Delta \mathrm{HBc}-\operatorname{siPLK} 1(* * * p<0.001)$. No significant difference between these two treatments was observed. Bioluminescence signals are expected to be directly proportional to the tumor metabolic activity. It is however worth mentioning that the signals here are obtained from both semiadherent in ascites and adherent cells forming tumor nodules in the peritoneal cavity, due to the nature of this tumor type. The metabolic activity of singly suspended cells is likely to be higher than those obtained from tumor nodules because the latter are likely to develop a necrotic core. To measure the solid tumor load, the weight of total tumors modules collected post-mortem was measured. Interestingly, contrary to the trends obtained from bioluminescence imaging, weights of solid tumors treated with $\mathrm{Z}_{\mathrm{HER} 2}-\Delta \mathrm{HBc}-\mathrm{siNEG}(0.72 \pm 0.26 \mathrm{~g}, * p<0.05)$ and $\mathrm{Z}_{\mathrm{HER} 2^{-}}$
$\Delta \mathrm{HBc}-\operatorname{siPLK} 1(0.72 \pm 0.14 \mathrm{~g}, * * p<0.01)$ were significantly lower than those of the PBS group $(1.01 \pm 0.14 \mathrm{~g}$ ) (Figure 6C). The level of PLK1 protein expression in HER2-expressing tumors was examined from the protein lysate of MDA-MB435-MLE tumors. PLK1 proteins were extracted from the solid tumor nodules, collected on day 28 at sacrifice, and the PLK1 expression was evaluated by Western blotting (Supporting Information Figure S4A). $\Delta \mathrm{HBc}-$ siPLK1 and $\mathrm{Z}_{\mathrm{HER} 2}-\Delta \mathrm{HBc}-$ siNEG were included to account for any nonspecific toxicity of the siRNA or the $\mathrm{Z}_{\mathrm{HER} 2}-\Delta \mathrm{HBc}$ particles, respectively. The PLK1 expression level of PBS group was normalized to $100 \%$ $\pm 1.49 \%$ relative to expression of GAPDH. Intraperitoneal treatment of $\mathrm{Z}_{\mathrm{HER} 2}-\Delta \mathrm{HBc}-$ siPLK1 hybrid particles showed slight but significant reduction in the PLK1 protein levels 
$(\sim 89.74 \% \pm 2.23 \%, * * p<0.01)$ (Supporting Information Figure S4B). Although these values appear lower than PBS group, the gene silencing effect might not be enough to infer with tumor growth in vivo.

3.7. In Vivo Biocompatibility. No significant difference in whole-body weight was observed between the PBS group and the other treatment groups (Supporting Information, Figure S5). The levels of the pro-inflammatory cytokine TNF- $\alpha$ were determined to assess the possibility of inflammation-mediated toxicity after intraperitoneal administration of $\mathrm{HBc}$ particles. ${ }^{37}$ TNF- $\alpha$ levels were measured in serum samples collected from MDA-MB-435-MLE tumor-bearing NSG mice after therapy. Sera from mice injected with LPS $(3 \mathrm{mg} / \mathrm{kg})$ intraperitoneally were taken at $1 \mathrm{~h}$ postinjection and used as a positive control. Significantly high levels of TNF- $\alpha(1048 \pm 320 \mathrm{pg} / \mathrm{mL}, * * * p$ $<0.001)$ were observed in the serum from mice treated with LPS (Supporting Information, Figure S6). On the other hand, no significant differences in serum TNF- $\alpha$ levels were found in mice receiving 7 doses of $\mathrm{Z}_{\mathrm{HER} 2}-\Delta \mathrm{HBc}-\mathrm{siNEG}, \Delta \mathrm{HBc}-$ siPLK1, or $\mathrm{Z}_{\mathrm{HER} 2}-\Delta \mathrm{HBc}-$ siPLK1 $(12-21 \mathrm{pg} / \mathrm{mL})$ intraperitoneally within 28 days compared to the PBS group (13 $\pm 7 \mathrm{pg} / \mathrm{mL}$ ).

Histological examination of the major organs (heart, lung, liver, spleen, and kidney) with H\&E staining exhibited no obvious histological changes compared to control animals (Figure 7 ). In mice treated with $\mathrm{Z}_{\mathrm{HER} 2}-\Delta \mathrm{HBc}-\mathrm{siPLK} 1$, tumors showed regions of necrosis (Figure 7, Supporting Information, Figure S7, red arrows), which was not observed in tumors from control and $\mathrm{Z}_{\mathrm{HER} 2}-\Delta \mathrm{HBc}-$ siNEG treated mice. Both early stage (fragmented and small nucleus) and late stage (ghost shells without nucleus) necrosis were found in necrotic areas, indicating an accumulative therapeutic effect of $\mathrm{Z}_{\mathrm{HER} 2}-\Delta \mathrm{HBc}-$ siPLK1 throughout the therapy time course.

\section{DISCUSSION}

In this study, we validated the utilization of recombinant HER2-targeting $\mathrm{HBc}$ particles as an efficient delivery carrier for siRNA. To the best of our knowledge, studies on delivering siRNA using $\mathrm{HBc}$ particles simultaneously with a specific HER2 targeting to cancer cells have not yet been reported. However, many studies have used $\mathrm{HBc}$ particles to deliver small molecules including oligonucleotides ${ }^{38}$ and drugs ${ }^{39}$ to cancer cells. Lee et al. reported the use of the $\mathrm{HBc}$ particles encapsulated with a green fluorescent protein by dissociating the $\mathrm{HBc}$ particles in the presence of urea and subsequently reassembling by dialysis to remove the denaturant. ${ }^{39}$ In another study, Beterams et al. successfully packaged up to 240 subunits of $17 \mathrm{kDa}$ nuclease into the interior of recombinant $\mathrm{HBc}$ particles. Interestingly, the packaged nuclease was enzymatically active and the structure of the particles was not affected. ${ }^{40}$

$\mathrm{HBc}$ particles like other virus-like particles have the capacity to load RNA. Encapsulating and loading nucleic acids within $\mathrm{HBc}$ particles is simpler than any other small molecules. This is due to the properties of nucleic acids, which are usually bigger, and the protein capsids have emerged to carry and encapsulate a similar type of cargo, in this case, their own viral genomes. In addition, dissimilar to the lipid-based, metal-based, and polymer-based nanocarriers, $\mathrm{HBc}$ particles are highly uniform, can be reproduced with an actual number of monomer proteins, and can be organized in a consistent arrangement. $\mathrm{HBc}$ particles are expected to possess a significantly reduced lot-to-lot variability and exact cargo release properties.
Furthermore, once the $\mathrm{HBc}$ particles managed to internalize in the targeted cells, they are able to disassemble and unleash all of the therapeutic molecules at once, compared with polymeric nanoparticles, which degrade and slowly release the loaded molecules over time. Even though slow cargo release might occasionally be propitious, in many cases, especially in cancer treatment, an immediate cargo release is preferred. $\mathrm{HBc}$ particles also have the capability to be functionalized chemically or genetically to exhibit fragments like antibody or peptide, for specific cellular targeting. ${ }^{41}$ Such characteristics make them distinguishable from other types of nanocarriers for nucleic acid delivery. These make HBc particles have more advantages than other nanoparticles. Taking advantage of the ability of $\mathrm{HBc}$ particles to encapsulate small biomolecules into their interior, we aimed at formulating recombinant $\mathrm{HBc}$ particles for delivery of siRNA capable of binding and possibly blocking HER2 receptors, allowing a combinatory approach to kill $\mathrm{HER}^{+}$cancer cells.

We demonstrated that siRNA encapsulation using method III showed the highest amount of siRNA encapsulated into $\mathrm{HBc}$ particles at the $1: 1 \mathrm{HBc} / \mathrm{siRNA}$ molar ratio, compared to method I and method II. Method I was not able to encapsulate a higher amount of siRNA compared to method III even though urea is a known denaturing agent for its compatibility with protein folding. This could be due to the incomplete reassembly caused by $\mathrm{NaCl}$. The ionic strength from the monovalent sodium ions might be able to trigger the $\mathrm{HBc}$ protein assembly, ${ }^{42}$ but not in an amount sufficient to increase the electrostatic charges between $\mathrm{HBc}$ protein monomers to cause complete reassembly of the proteins. Our result showed an enhancement of siRNA encapsulation using the osmotic shock in method II compared to method I. However, complete siRNA encapsulation was only achieved at 4:1 HBc/siRNA molar ratio. Studies reported that encapsulation of nucleic acids using osmotic shock is $\mathrm{pH}$-dependent. Braun et al. reported that the loading of oligonucleotide and plasmid DNA into polyoma VP1 virus-like particles achieved the highest encapsulation efficiency only at acidic $\mathrm{pH}$ of $5 .{ }^{38}$ In our study, $\mathrm{pH} 7.4$ was maintained throughout the experiment, which could be the reason for the lower siRNA encapsulation than expected. Nevertheless, we successfully encapsulated siRNA into $\mathrm{HBc}$ particles using method III, a new combination method involving the use of EGTA and DTT. EGTA and DTT were required for the particle disassembly as EGTA has high affinity to $\mathrm{Ca}^{2+}$. $\mathrm{HBc}$ particle assembly is highly $\mathrm{Ca}^{2+}$ dependent, $^{35,36}$ and DTT has the ability to break the disulfide bringing between $\mathrm{HBc}$ dimers. ${ }^{35}$

The blue intensity reflects quantitatively the amount of free migrating siRNA. Blue signals in the well are only semiquantitative (larger aggregates may float out of the wells during electrophoresis) and are representative of siRNA in the complexed form. In method I, it was not surprising to see a reduction in the amount of free migrating siRNA as the amount of $\mathrm{HBc}$ increased indicating an increased degree of siRNA complexation. In case of methods II and III, the complexation was efficient and occurred at all ratios used so that no free siRNA could be seen at all the tested ratios.

Instability poses a major problem in siRNA applications due to its degradation by the activity of serum or enzymes. We tested the stability of $\mathrm{HBc}-$ siRNA hybrid particles by challenging the hybrid particles with serum or RNase. Agarose gel results indicated that the $\mathrm{HBc}-$ siNEG hybrid particles confer great siRNA protection ability under several test 
conditions. In this study, $\mathrm{HBc}$ particles were expected to be able to protect siNEG from enzymatic degradation, but substantial signals can be seen at $0 \mathrm{~h}$ either due to partial instability or the presence of some surface-absorbed siRNA, which may have been detached in the presence of serum. The results explained the reduced uptake of siRNA in the presence of serum (Figure S3).

siRNA is an anionic macromolecule that is unable to enter cells by passive diffusion mechanisms, and thus an appropriate delivery system is needed to enhance its cellular uptake efficiency. Many studies have reported successful siRNA delivery in vitro using nanoparticles. For example, Lipofectamine2000, a cationic lipid formulation, is widely used for in vitro siRNA transfection, which succeeded in transfecting siRNA in a mouse's vascular endothelial cells. ${ }^{43}$ Recently, Pereira et al. reported the use of carbon nanotube-liposome hybrids to deliver siRNA in human epithelial lung carcinoma A549 cells. ${ }^{44}$ In our study, a successful delivery of siRNA in vitro was achieved using $\mathrm{Z}_{\mathrm{HER} 2}-\Delta \mathrm{HBc}_{\mathrm{AF} 488}-\mathrm{siNEG}_{\mathrm{Atto} 655}$ hybrids in two different HER2-expressing cancer cell lines. SKBR-3 cells, overexpressing HER2 receptors on cell membrane surface, showed an enhanced uptake of $\mathrm{Z}_{\mathrm{HER} 2^{-}}$ $\Delta \mathrm{HBc}_{\mathrm{AF} 488}-\mathrm{siNEG}_{\mathrm{Atto} 655}$ hybrids compared to $\Delta \mathrm{HBc}_{\mathrm{AF} 488}$ siNEG $_{\text {Atto655 }}$ hybrids. This could be attributed to the presence of $\mathrm{Z}_{\mathrm{HER} 2}$ affibody expressed on the particle surface that specifically binds the HER2 receptor. $^{26,45}$ In competition experiments using serum, intracellular uptake of $\mathrm{HBc}-$ siRNA hybrids was still taking place but with a slight reduction, which was also observed with the positive control, Lipofect-

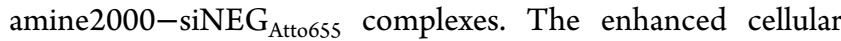
uptake of the $\mathrm{Z}_{\mathrm{HER} 2}-\Delta \mathrm{HBc}_{\mathrm{AF} 488}-$ siNEG $\mathrm{Atto655}_{\text {s }}$ hybrids revealed $\mathrm{Z}_{\mathrm{HER} 2}-\Delta \mathrm{HBc}$ as a promising system for the delivery of genetic material. Comparison and quantification of uptake was done by flow cytometry. Confocal laser scanning microscopy, to confirm site of localization inside the cells, could not be performed on MDA-MB-435 cells due to the semiadherent nature of the cells.

In the cytotoxicity assessments, a significant $10 \%$ cell death was observed for $\mathrm{Z}_{\mathrm{HER} 2}-\Delta \mathrm{HBc}-$ siNEG hybrids, whereas $\triangle \mathrm{HBc}-$ siNEG hybrids did not show any significant cytotoxicity. When the nonfunctional siNEG was substituted with a siRNA sequence specific for PLK1 gene, a further significant reduction in cell viability was achieved. The consequent quantitatively assessments by Western blotting of PLK1 protein expression confirmed the PLK1 knockdown after $\mathrm{Z}_{\mathrm{HER} 2}-\Delta \mathrm{HBc}-\mathrm{siPLK} 1$ hybrid treatments using the two HER2 positive cell lines, SKBR-3 or MDA-MB-MB435-MLE. The gene-silencing efficacy was even more efficient compared to Lipofectamine2000 transfection, which is encouraging for further in vivo investigation.

The choice of the location of the tumor model and route of administration was based on our previous study where tumor uptake of $\sim 10 \%$ of the total injected $\mathrm{HBc}$ dose per gram of tissue was achieved. ${ }^{20}$ Furthermore, even though the orthotopic inoculation of cancer cells in the mammary fat pad contributes a better model to resemble the early stages of breast cancer advancement, the IP tumor mouse model provides a much more precise representation of clinical disease progression of tumors, which includes metastatic dissemination. While combination of HER2-targeted HBc particles and siPLK1 (or siNEG equivalent formulation) resulted in apparent increase in cancer cell population based on whole body bioluminescence imaging, tumor weight measurement of solid tumor nodules showed contradicting results where $\mathrm{Z}_{\mathrm{HER} 2}{ }^{-}$ $\triangle \mathrm{HBc}$-based treatments (siNEG or siPLK1) displayed significant reduction in tumor weights. This discrepancy in findings using both techniques was unexpected. A possible explanation could be the fact that the cell line used in this study is a semiadherent cell line. ${ }^{28}$ Due to this property, tumor cells can be present in ascites fluid, also known as malignant ascites, or as adherent tumor nodules in vivo. ${ }^{46}$ It is expected that the bioluminescence signals measured are the sum of suspended cells and larger adherent tumor nodules. The discrepancy seen between the bioluminescence and tumor weight measurements may be due to the shift in tumor status from adherent nodules (low bioluminescence) to suspension form (higher bioluminescence). This seems to be primarily a function of the $\mathrm{Z}_{\mathrm{HER} 2: 342}$ affibody and not the siPLK1 treatment. Further studies are needed to understand how $\mathrm{Z}_{\mathrm{HER2} \text { :342 }}$ affibody-receptor binding may influence cell to cell communication and adhesion.

Immune response is always the main concern when it comes to gene therapy. Most of the toxicity associated with VLP nanocarriers arises from the innate and adaptive immune response to their capsids. Systemic administration of VLPs will cause the release of pro-inflammatory cytokines and chemokines, including TNF- $\alpha{ }^{47,48}$ Here, to abolish the immune response that might be induced from our $\mathrm{HBc}$ particles, we modified the major immunodominant region located between amino acids 75 and 83 with our $\mathrm{Z}_{\mathrm{HER} 2}$ affibody. This particular sequence has the capacity to exhibit a strong immune response. ${ }^{49,50}$ An establishment of targeting moieties at this sequence should be able to abolish a strong immune response by the host. ${ }^{51-53}$ The ELISA assay results showed no significant TNF- $\alpha$ level was observed in mice treated with recombinant $\mathrm{HBc}$ particles.

Western blotting data hinted that PLK1 silencing worked very slightly $(\sim 10 \%)$, but this is obviously not sufficient or therapeutically acceptable. It is acknowledged that the siRNA dose injected into mice was low compared what has been used in other studies. The siPLK1 dose was relatively low $(0.2 \mathrm{mg}$ of siRNA/kg per injection) compared to what have been reported in other studies with systemic siPLK1 administration. ${ }^{54,55}$ The limited dose was due to the low siRNA encapsulation efficiency obtained with the studied particles. Future work should focus on methods to improve siRNA loading so that higher siRNA doses, at lower nanocarrier dose, can be achieved. Taking together the results of therapy (weight measurements on solid tumor nodules) and Western blotting studies, one may think that both the intrinsic bioactivity of $\mathrm{Z}_{\mathrm{HER} 2}-\Delta \mathrm{HBc}$ and siPLK1 silencing took place. The overall potency however is minimal and needs further improvement. The histology analysis suggested that the administration of HER2-targeted $\mathrm{HBc}$ particles might induce apoptosis or necrosis to the solid tumors itself.

Another possible factor of the low efficacy might be due to challenges encountered with intraperitoneal delivery route of nucleic acids. It has been reported that local intraperitoneal delivery results in rapid clearance of the nanocarriers from the peritoneal cavity. This rapid clearing from the cavity to the systemic circulation most probably will limit the amount of nanocarriers that reach the actual target cells or tissues. ${ }^{56}$ In addition, IP fluid possesses a complex biological environment, so stability of our hybrids should also assessed under conditions mimicking those of intraperitoneal fluid for a better representation of in vitro to in vivo correlation. ${ }^{57}$ 


\section{CONCLUSION}

We developed a new siRNA delivery carrier composed of recombinant $\mathrm{HBc}$ particles and $\mathrm{Z}_{\mathrm{HER} 2}$ affibody. $\mathrm{Z}_{\mathrm{HER} 2}$ affibody on the particle surface allowed the recombinant $\mathrm{HBc}$ particles to be recognized by the HER2 receptors overexpressed on the cancer cell surface and be subsequently internalized. Furthermore, gene silencing studies with siPLK1 revealed that $\mathrm{HBc}$ particles were able to adequately silence PLK1 genes to commensurate levels to cationic lipid nanocarriers in vitro. Following intraperitoneal administration in intraperitoneal xenografts, combination of HER2-targeted HBc particles and siPLK1 did not produce any delay of tumor growth in vivo; however, targeted $\mathrm{HBc}$ particles induced a reduction in the weight of solid tumors. Mice after treatments did not show elevated TNF- $\alpha$ levels in serum, and no obvious histological changes in major organs were observed post-mortem indicating that our $\mathrm{HBc}$ particles are biocompatible in vivo.

\section{ASSOCIATED CONTENT}

\section{S Supporting Information}

The Supporting Information is available free of charge on the ACS Publications website at DOI: 10.1021/acsanm.8b00480.

Additional details of materials, siRNA encapsulation efficiencies by aldehyde/sulfate latex beads assay, in vitro cellular uptake of $\mathrm{HBc}$-siRNA hybrids subjected to serum competition, confirmation of siNEG $\mathrm{Atto655}_{\text {encap- }}$ sulation with beads coupling method, in vitro uptake studies in MDA-MB-468 and SKBR-3 cancer cells in presence or absence of serum, PLK1 gene silencing analysis in MDA-MB-435-MLE tumors, assessment of total body weight of HER2-expressing intraperitoneal tumor-bearing mice, TNF- $\alpha$ cytokine levels in serum after treatment, microscopic examination of tumor sections of MDA-MB-435-MLE tumor-bearing NSG mice (PDF)

\section{AUTHOR INFORMATION}

\section{Corresponding Author}

*K.T.A.-J. Tel: +44(0)20-7848-4525. E-mail: khuloud.aljamal@kcl.ac.uk.

\section{ORCID}

Akihiko Kondo: 0000-0003-1527-5288

Khuloud T. Al-Jamal: 0000-0001-5165-2699

\section{Present Address}

${ }^{\S}$ I.F.M.S.: Department of Pharmaceutical Chemistry, Kulliyyah of Pharmacy, International Islamic University Malaysia, Jalan Sultan Ahmad Shah, Bandar Indera Mahkota, 25200 Kuantan, Pahang, Malaysia.

\section{Notes}

The authors declare no competing financial interest.

\section{ACKNOWLEDGMENTS}

I.F.M.S. thanks Public Service Department, Government of Malaysia, for the Excellence Student Program studentship. Partial funding from Biotechnology and Biological Sciences Research Council (BB/J008656/1) and Worldwide Cancer Research (12-1054) are acknowledged. N.H. is a recipient of Graduate School King's Health Partner's scholarship. F.N.F. is a recipient of Educational Loan Scheme of Majlis Amanah Rakyat, Malaysia. J.B. is a recipient of Commonwealth Scholarships, U.K.

\section{REFERENCES}

(1) Devi, G. R. siRNA-based Approaches in Cancer Therapy. Cancer Gene Ther. 2006, 13, 819-29.

(2) Huang, C.; Li, M.; Chen, C.; Yao, Q. Small Interfering RNA Therapy in Cancer: Mechanism, Potential Targets, and Clinical Applications. Expert Opin. Ther. Targets 2008, 12, 637-45.

(3) Whitehead, K. A.; Langer, R.; Anderson, D. G. Knocking Down Barriers: Advances in siRNA Delivery. Nature Reviews. Nat. Rev. Drug Discovery 2009, 8, 129-38.

(4) Martinez, J.; Patkaniowska, A.; Urlaub, H.; Luhrmann, R.; Tuschl, T. Single-Stranded Antisense siRNAs Guide Target RNA Cleavage in RNAi. Cell 2002, 110, 563-74.

(5) Elbashir, S. M.; Harborth, J.; Lendeckel, W.; Yalcin, A.; Weber, K.; Tuschl, T. Duplexes of 21-Nucleotide RNAs Mediate RNA Interference in Cultured Mammalian Cells. Nature 2001, 411, 494-8.

(6) Iorns, E.; Lord, C. J.; Turner, N.; Ashworth, A. Utilizing RNA Interference to Enhance Cancer Drug Discovery. Nature Reviews. Nat. Rev. Drug Discovery 2007, 6, 556-68.

(7) Sun, Q.; Kang, Z.; Xue, L.; Shang, Y.; Su, Z.; Sun, H.; Ping, Q.; Mo, R.; Zhang, C. A Collaborative Assembly Strategy for TumorTargeted siRNA Delivery. J. Am. Chem. Soc. 2015, 137, 6000-6010.

(8) Laufer, S. D.; Detzer, A.; Sczakiel, G.; Restle, T. Selected Strategies for the Delivery of siRNA In Vitro and In Vivo. RNA Technologies and Their Applications 2010, 29-58.

(9) Tokatlian, T.; Segura, T. siRNA Applications in Nanomedicine. Wiley Interdisciplinary Reviews. Nanomedicine and Nanobiotechnology 2010, 2, 305-15.

(10) Zhu, D.; Yan, H.; Liu, X.; Xiang, J.; Zhou, Z.; Tang, J.; Liu, X.; Shen, Y. Intracellularly Disintegratable Polysulfoniums for Efficient Gene Delivery. Adv. Funct. Mater. 2017, 27, 1606826.

(11) Shim, M. S.; Kwon, Y. J. Efficient and Targeted Delivery of siRNA In Vivo. FEBS J. 2010, 277, 4814-27.

(12) Nayerossadat, N.; Maedeh, T.; Ali, P. A. Viral and Nonviral Delivery Systems for Gene Delivery. Adv. Biomed. Res. 2012, 1, 27.

(13) Pereira, S.; Lee, J.; Rubio, N.; Hassan, H. A. F. M.; Suffian, I. B. M.; Wang, J. T. W.; Klippstein, R.; Ballesteros, B.; Al-Jamal, W. T.; AlJamal, K. T. Cationic Liposome- Multi-Walled Carbon Nanotubes Hybrids for Dual siPLK1 and Doxorubicin Delivery In Vitro. Pharm. Res. 2015, 32, 3293-3308.

(14) Wei Shao, M.; Paul, A.; Abbasi, S.; Chahal, P. S.; Mena, J. A.; Montes, J.; Kamen, A.; Prakash, S. A Novel PolyethyleneimineCoated Adeno-Associated Virus-like Particle Formulation for Efficient siRNA Delivery in Breast Cancer Therapy: Preparation and In Vitro Analysis. Int. J. Nanomed. 2012, 7, 1575-86.

(15) Roldao, A.; Mellado, M. C.; Castilho, L. R.; Carrondo, M. J.; Alves, P. M. Virus-like Particles in Vaccine Development. Expert Rev. Vaccines 2010, 9, 1149-76.

(16) Garcea, R. L.; Gissmann, L. Virus-like Particles as Vaccines and Vessels for the Delivery of Small Molecules. Curr. Opin. Biotechnol. 2004, 15, 513-7.

(17) Choi, K. M.; Choi, S. H.; Jeon, H.; Kim, I. S.; Ahn, H. J. Chimeric Capsid Protein as a Nanocarrier for siRNA Delivery: Stability and Cellular Uptake of Encapsulated siRNA. ACS Nano 2011, 5, 8690-9.

(18) Kong, J.; Liu, X.; Jia, J.; Wu, J.; Wu, N.; Chen, J.; Fang, F. Pokemon siRNA Delivery Mediated by RGD-Modified HBV Core Protein Suppressed the Growth of Hepatocellular Carcinoma. Hum. Gene Ther: Methods. 2015, 26, 175-80.

(19) Choi, K. M.; Kim, K.; Kwon, I. C.; Kim, I. S.; Ahn, H. J. Systemic Delivery of siRNA by Chimeric Capsid Protein: Tumor Targeting and RNAi Activity In Vitro. Mol. Pharmaceutics 2013, 10, $18-25$.

(20) Mohamed Suffian, I. F. B.; Wang, J. T.-W.; Hodgins, N. O.; Klippstein, R.; Garcia-Maya, M.; Brown, P.; Nishimura, Y.; Heidari, H.; Bals, S.; Sosabowski, J. K.; Ogino, C.; Kondo, A.; Al-Jamal, K. T. Engineering Hepatitis B Virus Core Particles for Targeting HER2 Receptors In Vitro and In Vivo. Biomaterials 2017, 120, 126-138. 
(21) Cooper, A.; Shaul, Y. Recombinant Viral Capsids as an Efficient Vehicle of Oligonucleotide Delivery into Cells. Biochem. Biophys. Res. Commun. 2005, 327, 1094-9.

(22) Lochmann, D.; Jauk, E.; Zimmer, A. Drug Delivery of Oligonucleotides by Peptides. Eur. J. Pharm. Biopharm. 2004, 58, 237-51.

(23) Shan, W.; Zhang, D.; Wu, Y.; Lv, X.; Hu, B.; Zhou, X.; Ye, S.; Bi, S.; Ren, L.; Zhang, X. Modularized Peptides Modified HBc Viruslike Particles for Encapsulation and Tumor-targeted Delivery of Doxorubicin. Nanomedicine 2018, 14, 725-734.

(24) Ahmad, N. Polo-like Kinase (PLK) 1: A Novel Target for the Treatment of Prostate Cancer. FASEB J. 2004, 18, 5-7.

(25) Weiss, L.; Efferth, T. Polo-like Kinase 1 as Target for Cancer Therapy. Exp. Hematol. Oncol. 2012, 1, 38.

(26) Nishimura, Y.; Mimura, W.; Mohamed Suffian, I. F.; Amino, T.; Ishii, J.; Ogino, C.; Kondo, A. Granting Specificity for Breast Cancer Cells Using a Hepatitis B Core Particle with a HER2-targeted Affibody Molecule. J. Biochem. 2013, 153, 251-6.

(27) Blanchard, N.; Lankar, D.; Faure, F.; Regnault, A.; Dumont, C.; Raposo, G.; Hivroz, C. TCR Activation of Human T Cells Induces the Production of Exosomes Bearing the TCR/CD3/Zeta Complex. J. Immunol. 2002, 168, 3235-41.

(28) Wilkie, S.; van Schalkwyk, M. C.; Hobbs, S.; Davies, D. M.; van der Stegen, S. J.; Pereira, A. C.; Burbridge, S. E.; Box, C.; Eccles, S. A.; Maher, J. Dual Targeting of ErbB2 and MUC1 in Breast Cancer Using Chimeric Antigen Receptors Engineered to Provide Complementary Signaling. J. Clin. Immunol. 2012, 32, 1059-70.

(29) Rudolph, R.; Lilie, H. In Vitro Folding of Inclusion Body Proteins. FASEB J. 1996, 10, 49-56.

(30) Patra, A. K.; Mukhopadhyay, R.; Mukhija, R.; Krishnan, A.; Garg, L. C.; Panda, A. K. Optimization of Inclusion Body Solubilization and Renaturation of Recombinant Human Growth Hormone from Escherichia coli. Protein Expression Purif. 2000, 18, 182-192.

(31) Dell'Orco, D.; Xue, W.-F.; Thulin, E.; Linse, S. Electrostatic Contributions to the Kinetics and Thermodynamics of Protein Assembly. Biophys. J. 2005, 88, 1991-2002.

(32) Touze, A.; Bousarghin, L.; Ster, C.; Combita, A. L.; Roingeard, P.; Coursaget, P. Gene Transfer Using Human Polyomavirus BK Virus-like Particles Expressed in Insect Cells. J. Gen. Virol. 2001, 82, 3005-9.

(33) Chou, M. I.; Hsieh, Y. F.; Wang, M.; Chang, J. T.; Chang, D.; Zouali, M.; Tsay, G. J. In Vitro and In Vivo Targeted Delivery of IL-10 Interfering RNA by JC Virus-like Particles. J. Biomed. Sci. 2010, 17, 51.

(34) Jariyapong, P.; Chotwiwatthanakun, C.; Somrit, M.; Jitrapakdee, S.; Xing, L.; Cheng, H. R.; Weerachatyanukul, W. Encapsulation and Delivery of Plasmid DNA by Virus-like Nanoparticles Engineered from Macrobrachium Rosenbergii Nodavirus. Virus Res. 2014, 179, 140-6.

(35) Brinley, F. J., Jr.; Spangler, S. G.; Mullins, L. J. Calcium and EDTA Fluxes in Dialyzed Squid Axons. J. Gen. Physiol. 1975, 66 (2), 223-50.

(36) Choi, Y.; Gyoo Park, S.; Yoo, J.-h.; Jung, G. Calcium Ions Affect the Hepatitis B Virus Core Assembly. Virology 2005, 332, 454-463.

(37) Elsabahy, M.; Wooley, K. L. Cytokines as Biomarkers of Nanoparticle Immunotoxicity. Chem. Soc. Rev. 2013, 42, 5552-76.

(38) Braun, H.; Boller, K.; Lower, J.; Bertling, W. M.; Zimmer, A. Oligonucleotide and Plasmid DNA Packaging into Polyoma VP1 Virus-like Particles Expressed in Escherichia coli. Biotechnology and Applied Biochemistry 1999, 29, 31-43.

(39) Lee, K. W.; Tan, W. S. Recombinant Hepatitis B Virus Core Particles: Association, Dissociation and Encapsidation of Green Fluorescent Protein. J. Virol. Methods 2008, 151, 172-80.

(40) Beterams, G.; Bottcher, B.; Nassal, M. Packaging of Up to 240 subunits of a $17 \mathrm{kDa}$ Nuclease into the Interior of Recombinant Hepatitis B Virus Capsids. FEBS Lett. 2000, 481, 169-76.
(41) Rohovie, M. J.; Nagasawa, M.; Swartz, J. R. Virus-like Particles: Next-Generation Nanoparticles for Targeted Therapeutic Delivery. Bioengineering \& Translational Medicine 2017, 2, 43-57.

(42) Ceres, P.; Zlotnick, A. Weak Protein-Protein Interactions are Sufficient to Drive Assembly of Hepatitis B Virus Capsids. Biochemistry 2002, 41, 11525-31.

(43) Santel, A.; Aleku, M.; Keil, O.; Endruschat, J.; Esche, V.; Fisch, G.; Dames, S.; Loffler, K.; Fechtner, M.; Arnold, W.; Giese, K.; Klippel, A.; Kaufmann, J. A Novel siRNA-Lipoplex Technology for RNA Interference in the Mouse Vascular Endothelium. Gene Ther. 2006, 13, 1222-1234.

(44) Pereira, S.; Lee, J.; Rubio, N.; Hassan, H. A.; Suffian, I. B.; Wang, J. T.; Klippstein, R.; Ballesteros, B.; Al-Jamal, W. T.; Al-Jamal, K. T. Cationic Liposome-Multi-Walled Carbon Nanotubes Hybrids for Dual siPLK1 and Doxorubicin Delivery In Vitro. Pharm. Res. 2015, 32, 3293-308.

(45) Belousova, N.; Mikheeva, G.; Gelovani, J.; Krasnykh, V. Modification of Adenovirus Capsid with a Designed Protein Ligand Yields a Gene Vector Targeted to a Major Molecular Marker of Cancer. Journal of Virology 2008, 82, 630-637.

(46) Leonessa, F.; Green, D.; Licht, T.; Wright, A.; Wingate-Legette, K.; Lippman, J.; Gottesman, M. M.; Clarke, R. MDA435/LCC6 and MDA435/LCC6MDR1: Ascites Models of Human Breast Cancer. Br. J. Cancer 1996, 73, 154-61.

(47) Wonganan, P.; Croyle, M. A. PEGylated Adenoviruses: From Mice to Monkeys. Viruses 2010, 2, 468-502.

(48) Wajant, H.; Pfizenmaier, K.; Scheurich, P. Tumor Necrosis Factor Signaling. Cell Death Differ. 2003, 10, 45-65.

(49) Salfeld, J.; Pfaff, E.; Noah, M.; Schaller, H. Antigenic Determinants and Functional Domains in Core Antigen and $\mathrm{E}$ Antigen from Hepatitis B Virus. Journal of Virology 1989, 63, 798808 .

(50) Sallberg, M.; Ruden, U.; Magnius, L. O.; Harthus, H. P.; Noah, M.; Wahren, B. Characterisation of a Linear Binding Site for a Monoclonal Antibody to Hepatitis B Core Antigen. J. Med. Virol. 1991, 33, 248-52.

(51) Wynne, S. A.; Crowther, R. A.; Leslie, A. G. The Crystal Structure of the Human Hepatitis B Virus Capsid. Mol. Cell 1999, 3, $771-80$.

(52) Roseman, A. M.; Borschukova, O.; Berriman, J. A.; Wynne, S. A.; Pumpens, P.; Crowther, R. A. Structures of Hepatitis B Virus Cores Presenting a Model Epitope and their Complexes with Antibodies. J. Mol. Biol. 2012, 423, 63-78.

(53) Pumpens, P.; Borisova, G. P.; Crowther, R. A.; Grens, E. Hepatitis B Virus Core Particles as Epitope Carriers. Intervirology 2004, 38, 63-74.

(54) Polyak, D.; Krivitsky, A.; Scomparin, A.; Eliyahu, S.; Kalinski, H.; Avkin-Nachum, S.; Satchi-Fainaro, R. Systemic Delivery of siRNA by Aminated Poly(alpha)glutamate for the Treatment of Solid tumors. J. Controlled Release 2017, 257, 132-143.

(55) Malhotra, M.; Tomaro-Duchesneau, C.; Saha, S.; Prakash, S. Systemic siRNA Delivery via Peptide-Tagged Polymeric Nanoparticles, Targeting PLK1 Gene in a Mouse Xenograft Model of Colorectal Cancer. Int. J. Biomater. 2013, 2013, 252531.

(56) Dakwar, G. R.; Shariati, M.; Willaert, W.; Ceelen, W.; De Smedt, S. C.; Remaut, K. Nanomedicine-based Intraperitoneal Therapy for the Treatment of Peritoneal Carcinomatosis - Mission Possible? Adv. Drug Delivery Rev. 2017, 108, 13-24.

(57) Lu, Z.; Wang, J.; Wientjes, M. G.; Au, J. L. S. Intraperitoneal Therapy for Peritoneal Cancer. Future Oncol. 2010, 6, 1625-1641. 